E International

\title{
Port Hinterland Connectivity
}

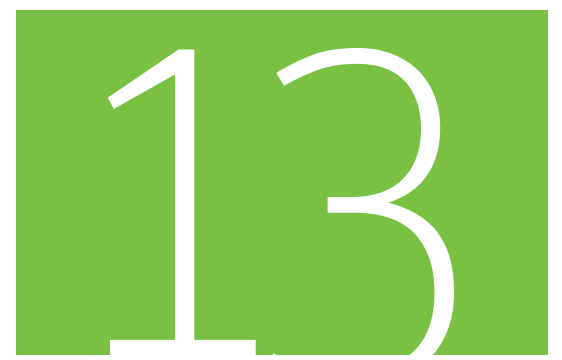

Discussion Paper 2015 13

Olaf Merk

International Transport Forum, Paris, France

Theo Notteboom

Dalian Maritime University,

China 


\title{
EInternational Transport Forum
}

\section{Port Hinterland Connectivity}

Discussion Paper No. 2015-13

\author{
Olaf Merk \\ International Transport Forum \\ Paris \\ Theo Notteboom \\ Dalian Maritime University \\ Peoples' Republic of China
}

May 2015 


\section{THE INTERNATIONAL TRANSPORT FORUM}

The International Transport Forum at the OECD is an intergovernmental organisation with 54 member countries. It acts as a strategic think-tank, with the objective of helping shape the transport policy agenda on a global level and ensuring that it contributes to economic growth, environmental protection, social inclusion and the preservation of human life and well-being. The International Transport Forum organises an annual summit of Ministers along with leading representatives from industry, civil society and academia.

The International Transport Forum was created under a Declaration issued by the Council of Ministers of the ECMT (European Conference of Ministers of Transport) at its Ministerial Session in May 2006 under the legal authority of the Protocol of the ECMT, signed in Brussels on 17 October 1953, and legal instruments of the OECD.

The Members of the Forum are: Albania, Armenia, Australia, Austria, Azerbaijan, Belarus, Belgium, Bosnia and Herzegovina, Bulgaria, Canada, Chile, People's Republic of China, Croatia, Czech Republic, Denmark, Estonia, Finland, France, Former Yugoslav Republic of Macedonia, Georgia, Germany, Greece, Hungary, Iceland, India, Ireland, Italy, Japan, Korea, Latvia, Liechtenstein, Lithuania, Luxembourg, Malta, Mexico, Republic of Moldova, Montenegro, the Netherlands, New Zealand, Norway, Poland, Portugal, Romania, Russian Federation, Serbia, Slovak Republic, Slovenia, Spain, Sweden, Switzerland, Turkey, Ukraine, United Kingdom and United States.

The International Transport Forum's Research Centre gathers statistics and conducts co-operative research programmes addressing all modes of transport. Its findings are widely disseminated and support policymaking in Member countries as well as contributing to the annual summit.

\section{Discussion Papers}

The International Transport Forum's Discussion Paper Series makes economic research, commissioned or carried out at its Research Centre, available to researchers and practitioners. The aim is to contribute to the understanding of the transport sector and to provide inputs to transport policy design.

ITF Discussion Papers should not be reported as representing the official views of the ITF or of its member countries. The opinions expressed and arguments employed are those of the authors.

Discussion Papers describe preliminary results or research in progress by the author(s) and are published to stimulate discussion on a broad range of issues on which the ITF works. Comments on Discussion Papers are welcomed, and may be sent to: International Transport Forum/OECD, 2 rue André-Pascal, 75775 Paris Cedex 16, France.

For further information on the Discussion Papers and other JTRC activities, please email: itf.contact@oecd.org

The Discussion Papers can be downloaded from:

www.internationaltransportforum.org/jtrc/DiscussionPapers/jtrcpapers.html

The International Transport Forum's website is at: www.internationaltransportforum.org

This document and any map included herein are without prejudice to the status of or sovereignty over any territory, to the delimitation of international frontiers and boundaries and to the name of any territory, city or area. 


\section{Table of contents}

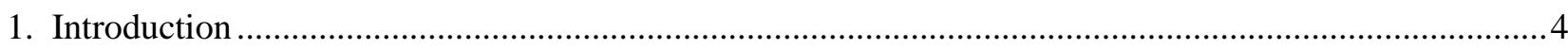

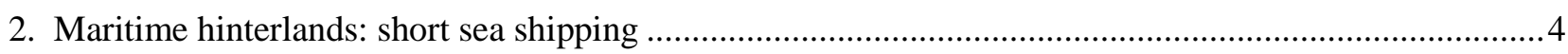

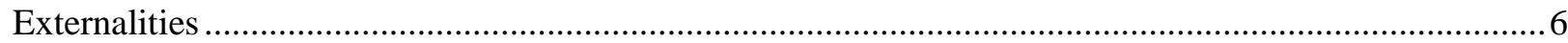

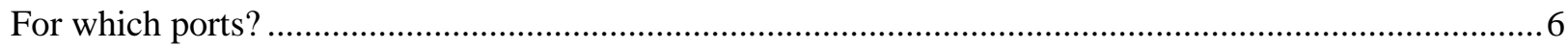

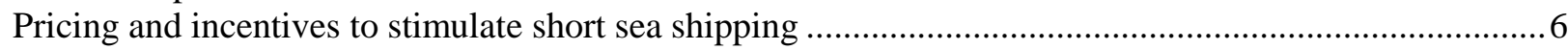

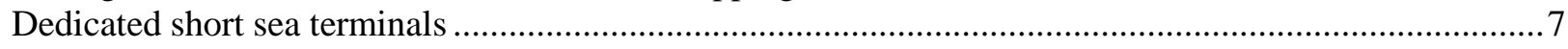

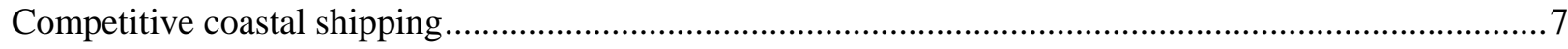

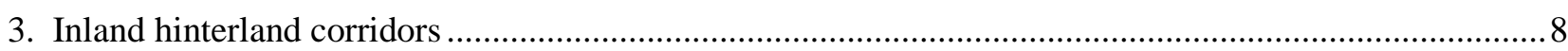

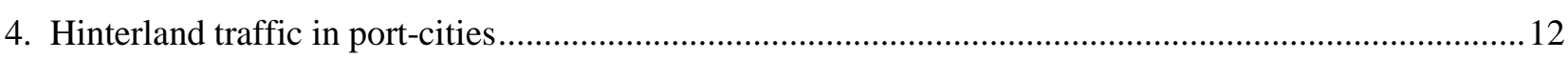

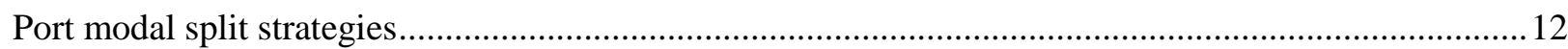

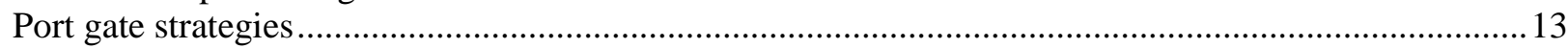

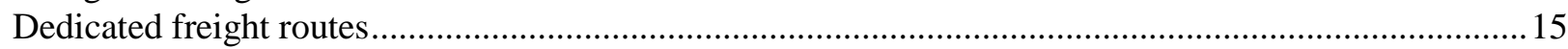

5. A multi-layer approach to port-hinterland freight mobility ...................................................................16

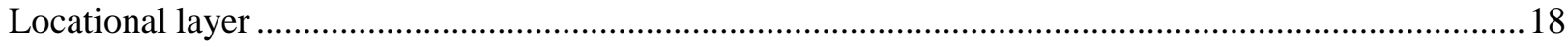

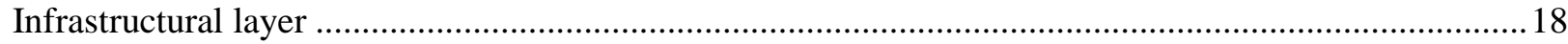

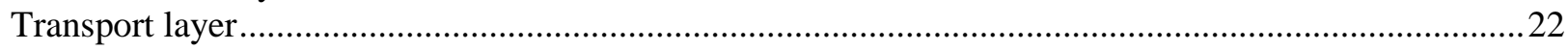

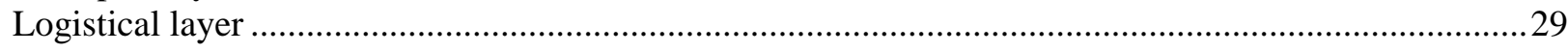

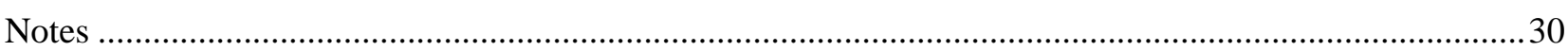

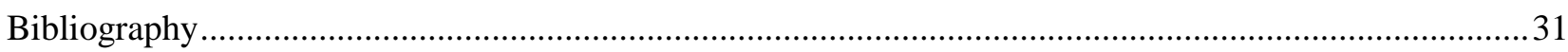




\section{Introduction}

The competitiveness of a seaport depends on the extent the cargo handled in the port can reach its hinterland destination (e.g. Acciaro \& McKinnon, 2013). The importance of hinterland connections has been recognised as one of the most critical issues in port competitiveness and development in most ports around the world. Upgrading of facilities and equipment, privatization of port operations and increased sophistication of berth planning have resulted in drastic reduction of ship turnaround times over the last decade. The smoothness of port-hinterland connections has not followed at the same pace. Increasing ship vessel size - and the related emergence of maritime hubs and spokes - will only exacerbate the bottlenecks related to port hinterland connectivity. One of the main issues related to the development of adequate hinterland connections in ports is the need to coordinate multiple actors often with conflicting mandates that constitute the mêlée of private and public institutions governing port hinterland infrastructure development.

Ports around the world have developed multiple strategies to improve their hinterland connections, in response to the challenges imposed by increasing traffic, shrinking public budgets, competition for road and rail use from passenger and personal vehicle and the proximity of many ports to densely urbanised areas. These strategies have resulted in a variety of policies such as the development of dry-ports (e.g. Bergqvist, Wilmsmeier, \& Cullinane, 2013a; 2013b; Roso, Woxenius \& Lumsden, 2009), improving stakeholder management (e.g. Bergqvist, 2012), developing appointment systems to improve port gate efficiency (e.g. Giuliano, \& O'Brien, 2007), extending operation times (e.g. Giuliano, \& O'Brien, 2008), extending the borders of the port beyond the port precinct (Veenstra, Zuidwijk \& van Asperen, 2012) or influencing the port modal split (e.g. Monios and Lambert, 2013). This paper identifies main port-hinterland connectivity challenges and current and potential policy responses to resolve these challenges. It dissects port hinterland connectivity in three related domains: maritime hinterlands, inland hinterland corridors, hinterland traffic in portcities, and multi-level governance framework related to hinterland transport.

\section{Maritime Hinterlands: Short Sea Shipping}

The short sea market is generally fragmented and underdeveloped. The short sea shipping market in the EU is largely captive, and the traffic that is in direct competition with road is very limited. The situation in the US is similar: coastal shipping for non-bulk goods is largely absent, apart from containerised shipments to Puerto Rico and Hawaii (Gouvernal et al. 2010). The transport chain is disconnected with many unrelated participants: the maritime leg has few connections with the inland legs (Paixao and Marlow, 2002, 2005). This lack of integration is considered to be one of the weaknesses of SSS, which explains its low level of attractiveness compared to road transport, which is also the case in North America (Brooks and Frost, 2004). 
The containerised short sea shipping market is not yet well developed, so shippers do not yet have the service frequencies that are offered by deep sea shipping, mainly because the traffic volumes are insufficient. Consequently, the maritime companies which provide short sea services have not yet developed partnership strategies such as consortiums or alliances that are common in deep sea shipping (Paixao and Marlow, 2002). As a result, short sea shipping has the image of a slow, unreliable and obsolete mode of transport. Explanations for the lower appeal of SSS are the lack of door-to-door multimodality, administrative complexity, efficiency of ports, port services and port hinterland connections, public investment in roads (Medda and Trujillo, 2010).

For the moment, there are few transport actors that have taken initiatives to better integrate short sea shipping in transport chains. Logistics service providers use short sea shipping services in some of the captive short sea shipping markets, but generally have limited incentives to stimulate short sea shipping as it would mostly compete with their primary interests, considering that they have in many cases truck fleets that compete with short sea shipping. Regular shipping lines, who would be the most likely to be interested in the short sea container market, are not involved in it at the present stage of development, because traffic volumes are insufficient to allow the organisation of end-to-end services with good frequencies (Gouvernal et al. 2010).

Short sea shipping is by nature a "broken" transport chain with friction costs. One of the friction costs is related to the costs incurred in double handling and in the storage of goods due to the inefficiency of flows. SSS adds extra nodes or transhipment points in the transportation chain: instead of trucks carrying the cargo directly from origin to destination, short sea vessels take over the longer haulage, and trucks make only the local pick up and the final delivery. At the transfer points of intermodal terminals, there are additional handling costs for the loading and unloading (Perakis and Denisis, 2008). An exception is formed by liquid and dry bulk cargoes that are often delivered to dedicated and private terminals, but generally the short sea shipping transport chain is not integrated but a "broken" chain, due to the lack of integration with the land modes at either end of the short sea service. This interoperability problem extends to information technology systems and documentary requirements as well. (Paixao and Marlow, 2002). So short sea shipping operations need to be carried out in the smoothest way possible and therefore eliminate all sorts of friction costs found in port environments.

Despite its current short comings, short sea shipping has huge market potential. Feasibility studies in various parts of the world have illustrated this. When short-sea shipping provides a more direct point-to-point routing and provides a solution to road traffic bottlenecks and urban congestion, it can be highly competitive with ground transport in terms of both cost and transit time - such as the Great Lakes corridor (Global Insight, 2006). The market in different US traffic corridors has enough density to enable relatively large vessels that provide scales economies in terms of operating and capital cost to be deployed with high enough service frequency to be competitive with trucking (Global Insight, 2006). Short sea shipping can be competitive in transporting cargoes to certain areas within the Baltic region, which suggests that it can assist in achieving mode equal modal splits within the EU. Nevertheless, it realistically achieves competitiveness only within certain areas with limited number of options and with port calls available. Short sea shipping would become more competitive when the use of vessels occupies a higher proportion of the total transport route, while road haulage is likely to continue its dominance for inland regions ( $\mathrm{Ng}, 2009)$. In addition, short sea shipping can be particularly competitive for heavy and hazardous shipments currently moving over road such as chemicals (Global Insight, 2006). 


\section{Externalities}

Internalising external effects is central to the competitive position of SSS. Maritime transport is the transport mode that has already internalised its external costs. The lack of a level playing field in the internalisation of transport external costs creates an artificial demand for mainly road transport (Paixao and Marlow, 2002). Some authors have observed that there is a blatant contradiction between the EU position of expecting that the market should provide and take the risk of providing the seaway infrastructure while tending to ignore that competing roadways and railway infrastructures are subsidised by member states and by EU grant aid such as TEN-T (Douet and Cappuccilli, 2011). There need to be at least two conditions in place for feasible short sea services: road congestion sufficiently severe to increase unreliability of land transport delivery times, and environmental savings sufficient that customers are willing to pay for them (Brooks and Frost, 2004).

The public benefits of short sea shipping are associated with relieving highway congestion, improving air quality and road safety. These benefits were identified and quantified for two cases of SSS in the US East Coast; a short route from New York to Boston; and a longer route from New York to Miami. In both cases, the use of Ro-Ro-ships appears to be very competitive compared with the truck mode in terms of projected required freight rate, because of the high external rates of trucks (National Ports and Waterways Institute, 2004).

\section{For which ports?}

The objective of major ports is to be elected as port of call by a large shipping company and by mega-alliances. Because not all ports can achieve the hub role within the maritime freight system, it could be an advantageous strategy for port authorities to grasp the opportunity to develop SSS types of ports, rather than compete as hubs (Medda and Trujillo, 2010). SSS traffic is seen as a means of helping secondary ports survive. However, there is a vicious circle: because the smaller ports do not have the cargo volumes to fill ships they cannot attract the carriers to provide a regular service; and because they cannot provide a regular service they cannot attract new customers (Gouvernal et al. 2010).

\section{Pricing and incentives to stimulate short sea shipping}

Several studies support that port efficiency and port charges are considered as barriers when choosing an intermodal transport chain with the use of SSS. In the US, the long shore labour rates may cause increased costs for cargo shipped via short-sea vessels. In addition, the Harbour Maintenance Tax (HMT) introduced in 1986, adds to the cargo transportation costs for shippers that use short sea shipping. The HMT is applied as a $0.125 \%$ ad valorem fee on the value of the commercial cargo loaded or unloaded on exports, imports, other shipments and passenger transport involving a port (Medda and Trujillo, 2010). The HMT is applied on both domestic and international containers that are transported by vessels using the US ports, but not on the cargo that is being transported by rail and truck. Many transport industry stakeholders are calling on the waiver of HMT for domestics SSS transport. The HMT has recently been repealed in the Great Lakes region. A study on the consequences of a possible elimination of the HMT concluded that the external monetary benefits from SSS outweigh the revenues from the HMT (Perakis and Denisis, 2008).

Ports seeking to improve short sea business might develop a differentiated port pricing policy that reflects the time-sensitive nature of the vessel. Less time-sensitive short sea vessels might call at a 
discount relative to time-sensitive deep sea or short sea vessels, encouraging some modal switching and a better allocation of port resources (Strandenes and Marlow, 2000).

An example of incentive programmes for short sea shipping includes the Motorways of the Sea framework: maritime corridors where SSS meets a number of conditions such as frequency, regularity and quality of service. The Marco Polo Programme II, part of the MoS programme is one of the most significant EU policy instruments to stimulate SSS. It supports private initiatives by way of a modal shift actions and catalyst actions, as well as start-up aid for maritime operators and awarding experienced companies maritime routes through specific criteria. At the same time, policies have been initiated for greater use of e-documentation and one-stop administrative shop in order to improve port and terminal nodes along the intermodal transport routes. In the US, there are currently 25 Marine Highway services operational (Medda and Trujillo, 2010).

\section{Dedicated short sea terminals}

Port authorities can influence the hinterland modal split by providing dedicated infrastructure. Some ports have developed dedicated short sea-terminals, in order to promote short sea shipping as a sustainable hinterland mode; in this way short sea shipping-vessels will not suffer from the lack of priority that they sometimes have in common user-terminals. In these terminals, the cargo is handled in the same way as international cargo, subject to many inspections and controls, leading to unnecessary costs and time loss (considering that the goods are not leaving or entering the country), which make coastal shipping uncompetitive in comparison with truck transport. The lack of such dedicated facilities is a chicken-and-egg issue: dedicated facilities would make sense if there is substantial coastal maritime trade, which is currently not the case, but it is not the case because there are no dedicated facilities.

\section{Competitive coastal shipping}

Short sea shipping from one coastal location to another in the same country is often subject to restrictive cabotage laws, excluding this kind of cargo transport to foreign-flagged ships, vessels with foreign staff, vessels that were not constructed in the country, or a combination of these restrictions. Such laws have had a very discouraging impact on short sea shipping.

Generally, the range of maritime cabotage regimes is wide, ranging from very restrictive in the US and Japan to very liberal in New Zealand and Australia (Brooks, 2009). The regime in the US, regulated by the Jones Act, requires not only US-flagged vessels and US crews, but also that the vessel is built in the US. Many countries are less restrictive and do not include the "built in" requirement. The regimes of Australia and New Zealand are very liberal and aim at creating a level playing field between international and coastal shipping. Although cabotage legislation is sensitive and difficult to reform, various countries have over the last decades liberalised their legislation; one of the more recent liberalisations was conducted in China.

In practice, many countries have exemptions to cabotage rules. For example, coastal shipping in Mexican waters is, as a general rule, reserved to Mexican shipowners with Mexican vessels, but if there are no Mexican-flagged vessels available, foreign flagged vessels may engage in cabotage trade under temporary cabotage permits granted by the Ministry of Communications and Transportation (SCT). These cabotage permits are granted for three-month periods and can be renewed seven times, with a maximum total of two years. After this period, the vessel would have to be flagged Mexican in 
order to continue operating in Mexican waters. Many countries have such exemptions, sometimes to the extent that the cabotage rules practically no longer apply.

\section{Inland Hinterland Corridors}

Port competitiveness is increasingly influenced by the process of developing trade corridors. The goal is to integrate the port system in a multimodal transportation network in order to improve market access, fluidity of trade and the integration in an industrial network. In this context, a port must have interfaces between major oceanic maritime trade and economic activities of ports and inland terminals that provide intermodal structures and connections between the forelands and hinterlands (Klink and Geerke, 1998, Notteboom and Rodrigue, 2005). Obviously, business transactions require an adaptation to hinterland means. Conversely, the amplification capacity of transport modes may allow the expansion of trade. These bonds of mutual causality are now present in the traffic of port cities. The quality and capacity of hinterland modalities, roads and relays are essential to any expansion of trade.

National involvement in ports often takes the form of investment in port infrastructure or portrelated infrastructure, such as hinterland corridors. Canada, with its Atlantic Gateway, is an example. Established in 2007, the Atlantic Gateway Federal-Provincial Officials Committee promotes on-going collaboration between the Government of Canada, the four Atlantic Provincial Governments, and the private sector in the development of the Atlantic Gateway and Trade Corridor. The Atlantic Gateway and Trade Corridor is a fully integrated multimodal transportation system that offers deep water ports, efficient and reliable road and rail networks with access to U.S. markets, and airports with air cargo access to/from international markets (Atlantic Gateway website).

The European Union is engaged in a major effort to promote modes of transport alternative to road transport. The Marco Polo program aims to promote all initiatives in this direction. The first phase of the Marco Polo Programme (2001-2006) has a budget of EUR 75 million. The goal was to reduce traffic congestion in Europe and return to the modal split of 1998 levels. The project involved the diversion of 12 billion tonne-kilometers of road transport to other modes of transport. In the specific area of river transport, the European Transport Ministers adopted in 2001 the Declaration of Rotterdam with a budget of EUR 820 million was also aimed at promoting the sector. The second phase of the Marco Polo Programme (2007-2013) aims to divert 144 billion tonne-kilometers off the road network. During the period 2003-2006, the Marco Polo program has funded 56 projects with 20 included a maritime component (Urli and Guy, 2009). The majority of these projects involved the development of RoRo-services. The European Commission has also launched the Naiads Programme in order to boost river transport. The program acts as a promotional tool for river navigation in public policy.

Rail infrastructure development has seen a major organizational change following rail liberalization: infrastructure managers are now responsible for the management and development of rail infrastructures in Europe. The access to services and infrastructure, capacity constraints on lines and in terminals, and path allocation procedures have become major issues in the liberalized market. The general idea is to strengthen cooperation between infrastructure managers and Member States in view of better managing the corridors. Such an approach requires investments in bottlenecks and the 
development of parameters for a sound infrastructure planning. It also demands efforts to improve the service quality along the corridors.

\section{Box 1: Rail freight transportation in Gothenburg}

Gothenburg has developed an extensive system of rail freight: every day, 25 shuttles are used to transport containers in 24 destinations in Sweden and Norway. This system can transport directly containers from ships by rail to distribution centers within a radius of $300 \mathrm{~km}$ around the city. The City of Gothenburg has decided to set up this system in 2000 to improve environmental and economic performance of the port. Indeed, the rail freight system, as designed in Gothenburg, facilitates faster transportation of goods to their final destination by limiting emissions of greenhouse gases. In 2002, thanks to the joint financing of the Swedish Ministry of Transport, the Port Authority of Gothenburg and Västra Götaland Region, the city has set up an infrastructure for multimodal transport of goods by rail through the relocation of customs to distribution centers in the hinterland, which limits transhipments. Once arrived at the distribution center, trucks are responsible to transport containers to their final destination. This system is used for the transport of containers of 20 and 40 feet, but in order to have more customers to take advantage of this system, the Port Authority has also implemented innovative container formats, which makes it possible to transport rolls of paper by train.

The rail freight system in Gothenburg is known for its benefits in terms of costs. The speed of container transport has increased as a result of several mechanisms. First, the arrival of the rail freight system has helped to reduce congestion caused by trucks from the port within the confines of the city. This system allows reducing around 360 trucks per day in the city. Secondly, customs decided to operate directly in the hinterland so that goods can be transported more quickly to their final destination. This customs decentralisation also allows more cargo to pass through the Port of Gothenburg which might explain the significant growth in container traffic at the Port from 2001 (which corresponds more or less at the date of implementation of the rail freight system) and 2011: $61.2 \%$.

Each year 200,000 containers are sent to a hinterland of 300km around Gothenburg. This area corresponds roughly to the largest industrial area in Scandinavia, since $70 \%$ of Scandinavian industries are within 500km around Gothenburg. Business needs of the region in terms of import and export helps to explain the enthusiasm of policymakers for the rail freight system. In 2011, 887,000 containers passed through the Port of Gothenburg and 374,000 of them were transported to the hinterland by rail freight, which represents approximately $40 \%$ of traffic. The objective is to increase the port number of containers transported by rail in 2020 to $50 \%$ by increasing the efficiency of the system. To do this, the Port Authority has implemented a participatory assessment of rail freight allowing multiple user categories to highlight areas for improvement. Finally, the efficiency of rail freight from the Port of Gothenburg is enhanced by the ability of the city to integrate it into broader urban development plans, strengthening its coherence.

The success of the rail freight from the port of Gothenburg can be explained by three main factors: a collaborative governance system controlled by an efficient port authority efficient, the importance of public investment and the ability to meet the expectations of users. This system of governance has been made possible by the change of the legal status of the port in 2010, from a municipal service to a public company. Since 2010, the Port Authority is responsible for strategic decisions and cooperates with a large number of players, that is to say, the municipality of Gothenburg, the Ministry of Transportation, the Region Västra Götaland, customs and many operative private actors within the system, for both trains and terminals. The Port Authority is responsible for the coordination of the different actors and has the ability to mediate interests. This allows for better cooperation between actors under the supervision of the Port Authority. Similarly, the number of actors involved in the decision-making process explains the relevance of urban plans associated with the port (such as the proposed Comprehensive Plan and Marieholm, 2009). The effectiveness of the implementation of the system also helps explain its success. In fact, the project was approved at city council in 2000. Between 2000 and 2002, 6 rail shuttles were built and 25 of them work in 2011. The rapid development of rail freight has been facilitated by the importance of public investment for infrastructure construction.

Finally, the success of the system can be explained by the ability of public actors to focus their strategy according to the needs of private actors, such as the establishment of specific cargo for transport companies without containers. Meanwhile, the use of rail freight system reduces costs for users: the speed of loading and unloading cargo is reduced, which reduces their parking fees at the dock. Similarly, storage of goods outside the port reduces costs (insofar as the application for the same warehouse is reduced) and finally, the port offers differentiated tariffs for customers choosing to reduce their particulate emissions. The increase in the number of containers transported by rail since the creation of this system, demonstrates its effectiveness and the enthusiasm of users. 
While markets have been liberalized, the creation of pan-European/cross-border railway services is still hindered by technical issues such as differences in railway gauges (cf. Iberian Peninsula, Russia), electric networks and signaling systems. The existing lack of technical harmonization historically has had a huge impact on the structuring of rail infrastructure networks in Europe and also on the potential for the development of cross-border rail services. In the past years, a wide range of actions has been launched in the area of interoperability, infrastructure management (cf. RailNetEurope) and the development of a priority network for rail freight in Europe. The implementation of the European Railway Traffic Management System (ERTMS ${ }^{1}$ ) and the identification of rail corridors are major steps forward. It is expected that by the reference year 2030 the technical hindrances for truly pan-European rail services will have been alleviated.

\section{Figure 1. TEN-T Core Network Corridors (Trans-European Transport Network)}

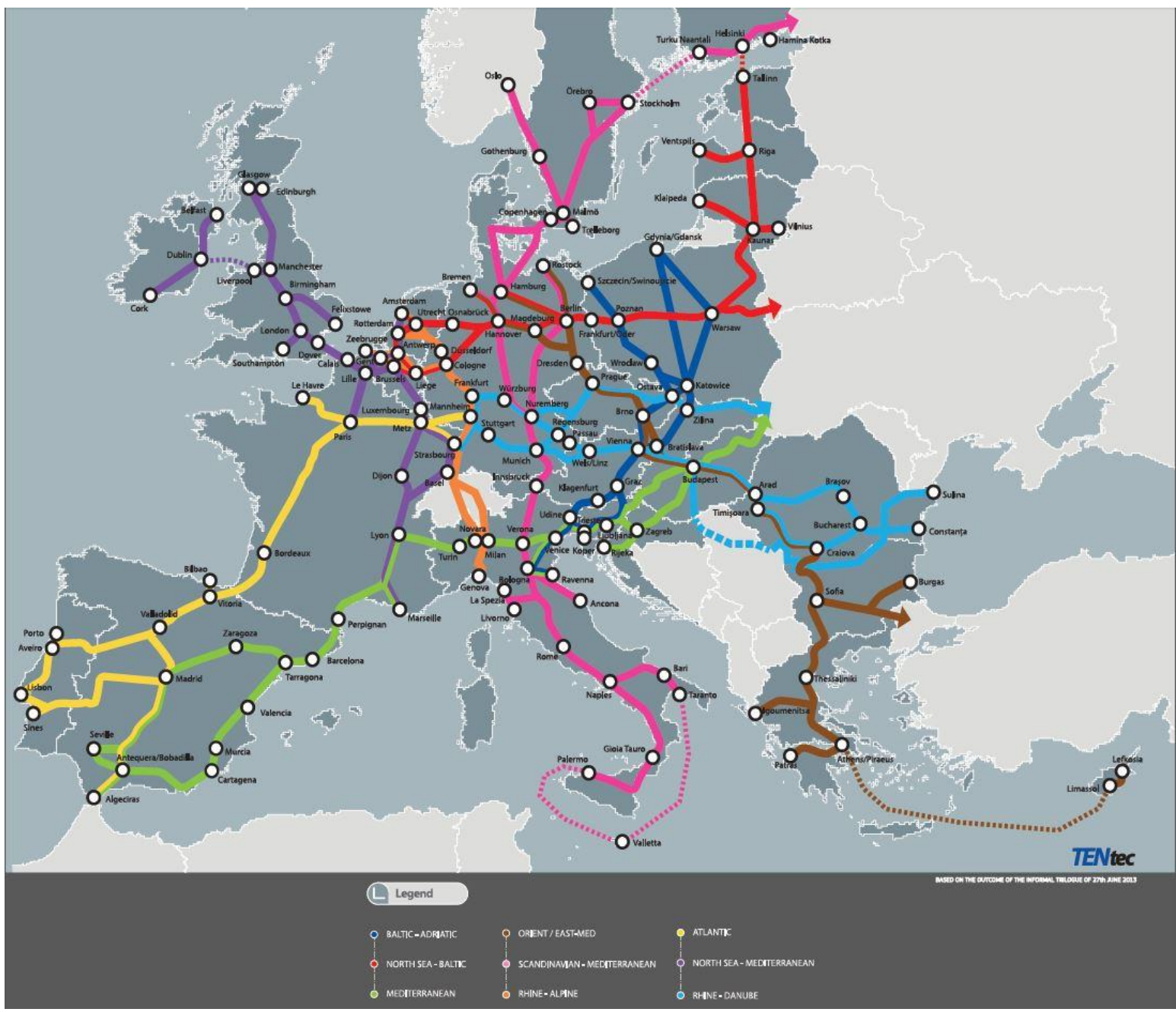

Source: European Commission, TENtec.

Intercontinental rail networks are developing fast, particularly in relation to Russia, Central Asia and East Asia. The east-west rail corridors are a set of railway lines connecting East Asia and the western part of Russia with the Eastern part of Russia. One of the main arteries is the Trans-Siberian Railway which connects St. Petersburg with the port of Vladivostok via cities like Moscow, Omsk, Novosibirsk and Irkutsk. Other primary rail connections are the Trans-Manchurian Railway, the Trans-Mongolian Railway and the Baikal Amur Mainline (BAM - opened in 1991) which all coincide 
with the Trans-Siberian in the western sections but diverge north of Mongolia just before or after lake Baikal (see figure 1.14). Total TEU volumes on the Trans-Siberian railway reached 840,000 TEU in 2014. The Russia-China trade lane accounts for about half of the total. Russian railway operators RZD plans to invest $\$ 6$ billion by 2020 to bring the average travel time to less than eight days, with a speed of about $1200 \mathrm{~km}$ a day (now $900 \mathrm{~km}$ per day).

At the end of 1992 China inaugurated a new railway line which connects China's east coast to the Kazak border and the existing Eurasian railway network. The resulting New Asia-Europe Land Bridge totals 10,900 km. However, freight movements remained low for long (only 257 TEU in 1995 due to high cross-border rail tariffs, complex paperwork, long transit times, poor freight tracking and intense competition from the Trans-Siberian Railway and the all-water route via the Suez Canal. The Eurasian land bridges got a new impetus with the "Beijing-Hamburg Container Express" launched in January 2008. The rail service covers 6,200 miles in 15 days through Mongolia, the Russian Federation, Belarus and Poland. In January 2015, a train carrying 30 containers drove from Yiwu (Zhejiang Province in China) to Madrid covering 8,111 miles in three weeks via Kazakhstan, Russia, Belarus, Poland, Germany and France. This new service added Spain to a route that already links Chongqing to Duisburg and Antwerp five times a week. The Chinese government launched the New Silk Road initiative in November 2014 backed by a 40 billion dollar investment program to break the connectivity bottleneck in Asia. Kazakhstan plays a central role in this new initiative, e.g. via the development of a dry port and rail yard at Khorgos, in the desert on its eastern border with China. Volume passing from China to Europe across Kazakhstan amounted to 'only' 6,600 FEU in 2013 and 10,000 FEU in 2014, but growth prospects are strong given the New Silk Road program.

Figure 2. Railway corridors connecting Asia and Europe

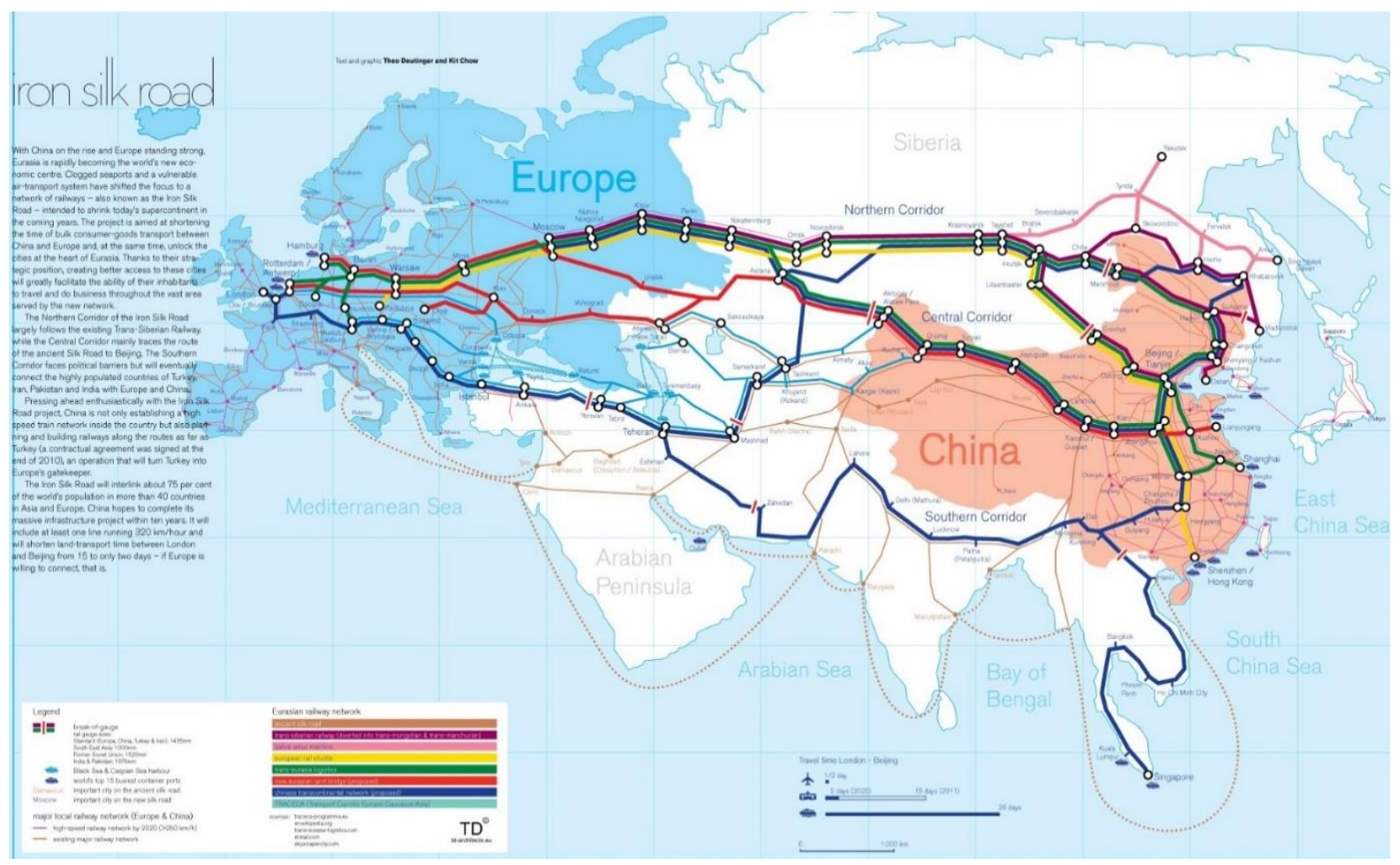


While volumes currently transported on the rail corridors linking Asia to Europe are still quite low, this development is of relevance to the long term development of the port of Antwerp as the port already has a fixed rail connection with China (i.e. Chongqing) and as volume growth on the rail corridors is expected to be strong in the coming decades.

\section{Hinterland Traffic in Port-Cities}

\section{Port modal split strategies}

Reducing port-related road congestion can be realised by shifting towards other hinterland transport modes, such as rail, inland waterways, pipelines and short sea shipping. In practice, the hinterland traffic of most ports is dominated by trucks (Figure 3). Even the ports with the highest shares of non-truck hinterland traffic rarely manage to achieve more than half of its traffic by other means than trucks. However, it is truck traffic that causes most of the congestion in and around port areas; and it is truck traffic that generally generates most external costs. So many ports have in their strategic plans formulated targets for a modal shift of hinterland traffic towards rail and water. This is not easy, as not all ports are connected to a well-developed system of inland waterways or of railway lines. As a result, the modal split shares of most ports tend to remain fairly stable, but there is a variety of instruments that can be applied, including incentives schemes, dedicated infrastructure and competition in hinterland modes.

Figure 3. Hinterland transport modal splits in selected ports

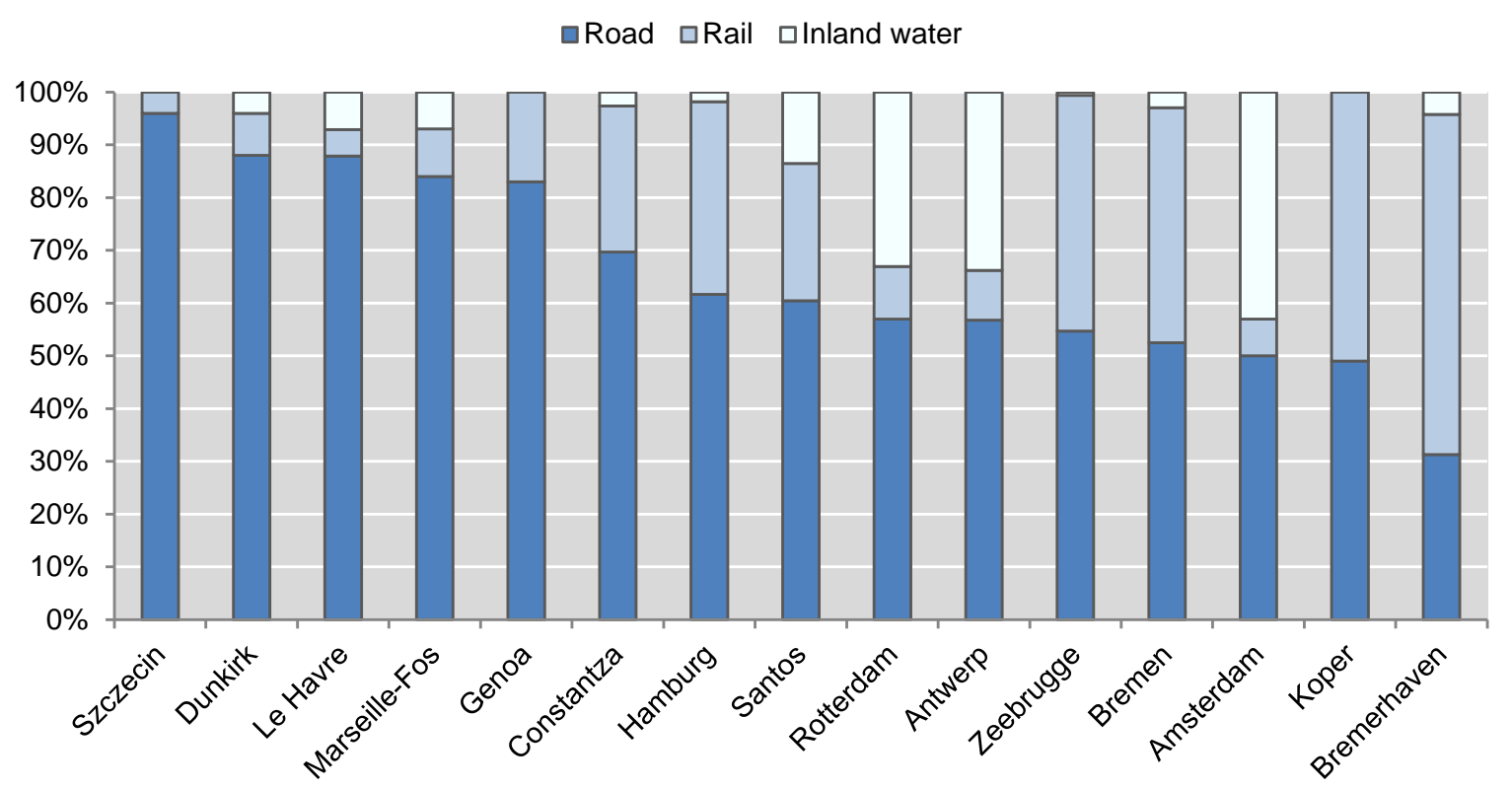

Source: OECD (2014). 


\section{Port gate strategies}

One of the main port-related traffic mitigation measures relates to reduction of idle trucks at port gates. This presents highly relevant challenges in many port-cities, leading to urban congestion and environmental impacts. Main policy instruments in this respect are terminal appointment systems, extending gate hours and virtual container yard systems. The section below assesses these instruments as applied in ports and port-cities. In addition, there have been simulation models, but most simulations have represented gate strategies as shifts in demand and have not combined those demand shifts with actual gate operations, so the results of these simulations will not be treated here.

\section{Truck appointment systems}

The goal of appointment systems is to reduce road congestion at port terminals, by giving a preferential treatment to trucks that choose to schedule an appointment. The idea is that an appointment system would allow terminals to spread truck movements more equally over the day. Terminal gate appointments are usually voluntary, but have in a few cases also been imposed on terminals by law. E.g. in 2003 the State of California passed a bill, the California Assembly Bill (AB) 2650, that required 13 terminals at the ports of Oakland, Los Angeles and Long Beach to create an appointment system or face a charge of USD 250 for each truck idling more than 30 minutes.

The results of terminal gate appointment systems can be positive. The Gate Entry Management (GEM)-system in the port of New Orleans and the WebAccess system of Georgia Ports Authority (GPA) are considered to be success stories. Both systems are web-based applications that allow dispatchers to schedule appointments and provide information for pre-clearance prior to truck arrival at the terminal; WebAccess allows customers 24 hours per day access to update data on container shipments. These applications have improved traffic flow, increased terminal throughput and improved productivity for trucking companies and terminal operators, with a reduction of truck turnaround times by $30 \%$ on average in the case of GPA (US EPA, 2006).

At the same time, the terminal appointment system in the ports of Los Angeles and Long Beach is generally considered to be ineffective. The majority of the terminal operators did not view appointments as an effective operational strategy, and they did not facilitate the implementation of the instrument. Only a small percentage of trucks used the appointment systems, and these appointments were not given a priority, so queues were not reduced. Other elements that contributed to the lack of success were the inability of terminals to enforce appointments, the lack of willingness of drayage operators to participate in the programme, the lack of dedicated appointment lanes and the fact that the system was opposed from the outside. Similar truck idling bills have been introduced in Illinois, Rhode Island, Connecticut and New Jersey. Conditions for such systems to work would be a large proportion of trips that use appointments and priority to appointment trips to realise significant time savings (Giuliano and O'Brien, 2007; Giuliano et al. 2008).

\section{Incentives for off-peak traffic}

Extended gate hours attempt to redistribute the arrival times of trucks to port terminals throughout the day. The idea is that offering incentives to use off-peak hours will reduce congestion at port terminals, as well as nearby roadways. The most well-known example of extended gate hours is the PierPASS programme implemented in the ports of Los Angeles and Long Beach, which includes a Traffic Mitigation Fee (TMF) for drayage transactions made during peak hours, with exemptions for off-peak hours. The TMF fee is USD 50 during peak hours (originally USD 40), with exemptions during off-peak hours and for empty containers and intermodal transport using the Alameda corridor. The Beneficial Cargo Owners (shippers, consignees, or their agents) are responsible for the payment 
of the fee. Neither the trucking community nor the ocean carriers is assessed a fee under this program. In addition to providing an incentive for the shippers to divert cargo to off-peak time periods, the TMF also serves to defray the additional costs incurred by the terminal operators to keep terminal gates open at night and on weekends. Extended gate hours were also part of trial programmes in the port of New York/New Jersey.

The instrument was effective in Los Angeles/Long Beach, but not in New York/New Jersey. The PierPASS programme was successful in reducing daytime truck arrivals from $90 \%$ to $66 \%$ within a few months after introduction (Cambridge Systematics, 2009), and it reduced daytime traffic on a nearby freeway by $13 \%$. The average share of off-peak cargo from July 2005 to September 2006 was $40 \%$, with an average rate of increase of about $8 \%$ per week. Little sensitivity to the fee itself was found, which suggests that adjustment costs, such as additional opening hours, more storage space for cargo etc., are the key factor in cargo scheduling (Giuliano and O'Brien, 2008). The programme was also positively perceived: drayage operators felt that extended operating hours of terminal gates had a positive impact on the overall efficiency of drayage operations, according to a survey (cited in Cao and Karafa, 2013). The only drawback of the programme was that ports experienced heavy queues just before the opening of the off-peak hours, due to a flaw in the design of the programme: a variable pricing scheme would alleviate this side effect. In contrast, the pilots carried out in the Maher Terminals and the Port Newark Container Terminal at the Port of New York/New Jersey were not considered to be a success. Only very few truckers were utilising the off-peak hours (7\% of daily truck moves at Maher Terminals), despite the much shorter truck turn times (Spasovic et al., 2009).

The differences in effectiveness could be explained by different market and political conditions. Unlike New York, the situation in LA/Long Beach was characterised by persistent political pressure from the environmental lobby, with port terminals run by large shipping lines, which have more power to coordinate along the whole logistics chain and with cargo predominantly handled for large national shippers, requiring less coordination efforts than the more fragmented customer base in New York. Moreover, not many customers in New York are open at night and there are limited inland port distribution centres, so that truckers would have nowhere to go if they would pick up a container from the port at night (Spasovic et al., 2009). Other conditions that contributed to the success of the programme in Los Angeles/Long Beach were the amount of off-dock rail, environmental and congestion pressures, as well as inter-port competition, with the possibility that cargo would be diverted if terminal operations would not be efficient (Cambridge Systematics, 2009).

\section{Extended gates and dry ports}

In addition to these measures, regional approaches towards freight transport, e.g. distribution centres and extended gates, might be needed to create enough critical mass for non-truck transportation. Trucks generally have a competitive advantage for shorter distance transport; only as distances are longer does freight transport by train generally become a competitive transport mode. Large economies of scale can be reaped, but a certain logistical organisation is required for this in the form of distribution centres in which large amounts of containers and cargo can be grouped before being dispatched to individual destinations. Such a system of selective dry ports or distribution centres has made it possible for relatively small container ports such as Gothenburg to achieve high railway shares in total hinterland traffic. A related approach is that of extended gates, which basically relocated part of the port closer to the hinterland, by displacing cargo handling, customs and other procedures towards an inland port, allowing for a de-congestion of the port. Such a concept is welldeveloped by the port of Antwerp that has engaged in a large set of partnerships creating a network of inland extended gates. Ports have generally become more aware of the need to be better linked to hinterlands, with various ports taking stakes in inland terminals and distribution centres, creating dry ports, merging with inland ports and facilitating part of the hinterland transportation. 


\section{Dedicated freight routes}

In some countries dedicated freight lanes and corridors are created. Such freight corridors facilitate fast and uninterrupted freight transportation, as it allows for limited intermingling of freight with urban passenger transportation. These corridors differ in length, with the Alameda Corridor being $32 \mathrm{~km}$ long, connecting the ports of Los Angeles and Long Beach to the transcontinental railways in the US (Box 2), to the Rotterdam Betuwe-line representing $120 \mathrm{~km}$ dedicated rail track to Germany (Box 3), up to the planned dedicated freight corridor between Delhi and Mumbai of approximately $1500 \mathrm{~km}$. Although these dedicated freight corridors are neither guarantee nor necessity for achieving high railway shares in the total hinterland transportation, countries in which freight and passenger railways are mixed will have to find ways to accommodate their co-existence. In several countries, passenger rail gets priority, to the detriment of rail freight. Inland waterways are used in many countries to link seaports with inland destinations and several seaports have financial participations in inland ports, in order to strengthen their hinterland connections.

\section{Box 2: Alameda corridor}

Alameda Corridor is a $32 \mathrm{~km}$ long freight rail cargo facility, connecting the transcontinental rail lines near downtown Los Angeles, California to the Ports of Long Beach and Los Angeles. The project is one of the largest public infrastructure works in the nation with a $\$ 2.4$ billion investment. The operation of the corridor commenced in 2002. The centrepiece of the project is the Mid-Corridor Trench, which carries freight trains on triple track lines in an open trench that is $16 \mathrm{~km}$ long, $10 \mathrm{~m}$ deep and $15 \mathrm{~m}$ wide. The corridor was built by the Alameda Corridor Transportation Authority (ACTA), which is a joint powers authority formed by the cities and ports of Long Beach and Los Angeles in 1989. It is a public-private partnership project that involved various stakeholders, such as the two ports, Los Angeles County Metropolitan Transportation Authority (LACMTA), Southern California Association of Governments (SCAG), private railroad companies Union Pacific (UP) and Burlington Northern Santa Fe (BNSF), as well as the eight cities that the corridor passes. Its funding came from a unique mix of public and private sources, including a federal loan, grants from the LACMTA, user fees paid by the railway companies, investments from the ports, and revenue bonds. According to the ACTA, the goal of the Alameda Corridor is to consolidate train traffic and eliminate at-grade conflicts, as well as improving the air quality in the Southern California basin through reducing traffic congestion at rail crossings.

As a dedicated intermodal railway designed to improve the efficiency of transporting container cargo from the two ports to the national rail system, there are a number of benefits generated by the Alameda Corridor. It has resulted in more efficient rail movement, with a reduction of train transit time from over 2 hours to 45 minutes, as well as increased train reliability. Moreover, it eliminated conflicts at 200 at-grade rail crossings that reduce traffic delays and emissions from idling automobiles and trucks. As of April 2012, which marked its 10-year anniversary, ACTA estimated that more than 150,000 trains and moved more than 20 million TEUs (twenty-foot equivalent units) through the Alameda Corridor, resulting in more than 13,000 tons of total emission reductions from the consolidation of freight rail operation and the alleviation of traffic congestion at rail crossings in the Southland. The ACTA also provided training to about 1,300 area residents and created more than new 1,000 jobs during its construction process. Currently, the corridor has average daily traffic of 43 trains and cargo volume of 12,359 TEUs.

One key factor to the timely completion of the Alameda Corridor was the process to reach a consensus among various stakeholders from the public and private sectors. The ACTA was able to resolve conflicts of interests between stakeholders and created a publicly acceptable project by taking actions to accommodate their needs and concerns (Agarwal et al, 2004). The ACTA had negotiated settlements and signed memoranda of understanding (MOU) with each mid-corridor city, as well as to provide assistance in local economic development measures in order to secure their cooperation with project approval and construction. 


\section{Box 3: Betuwe line}

The Betuweroute is a double track dedicated freight rail track towards Germany and into Europe. For the section from Rotterdam to the large shunting yard at Kijfhoek existing tracks were reconstructed, but three quarters of the line is new, from Kijfhoek to Zevenaar near the German border. The rail part in Germany is referred to as the Hollandstrecke. Together they formed project no. 5 of the Trans-European Transport Network program (TEN-T). The first discussions on the dedicated freight track go back to 1985. Work on the Dutch part of the track began in 1998. Before and during its construction the route generated a lot of controversy in political and community circles. In 2000 the Court of Audit stated that promoting river transport should have been considered as a realistic alternative. In 2004 the Centraal Planbureau concluded that the construction would never pay its way. Delayed by two years, the railway was finished mid-2007, at a cost of 4.7 billion euro, more than two times the original budget.

The Betuweroute is managed by Keyrail. The shareholders of Keyrail are Prorail (50\% - Prorail is the rail infrastructure manager in the Netherlands), Rotterdam Port Authority (35\%) and Amsterdam Port Authority (15\%). In 2010 , rail traffic on the $120 \mathrm{~km}$ stretch between Kijfhoek and Zevenaar increased by almost $80 \%$ to 17,600 trains. The market share of the Betuweroute in comparison with the other border crossings for freight transport by rail to and from Germany has increased to more than $70 \%$ in 2010 compared to $45 \%$ in 2009 . The main motor behind this growth has been active tariff policy and the electrification - at the end of 2009 - of the Port Railway Line, the stretch between the Maasvlakte and the Kijfhoek shunting centre. As a result of this, many carriers switched from the 'mixed network' to the Betuweroute. In addition, the Port of Amsterdam got connected to the Betuweroute in March 2011 via a railway connection to the Betuweroute near Meteren/Geldermalsen. As such the Betuweroute is now serving both ports. Keyrail expects the number of trains on the Betuweroute to increase to 500 a week by the end of 2011 or a market share of about $75 \%$.

\section{A Multi-Layer Approach to Port-Hinterland Freight Mobility}

Four inter-related layers, ranging from a spatial to a functional perspective, affect port-hinterland freight mobility and the routing of goods through port systems (see Figure 4). The upward arrow depicts that each layer valorizes the lower layers. The downward arrow represents the demand pull exerted from the higher levels towards more fundamental layers. In a demand-driven market environment the infrastructural layer serves the transport and logistical layers. 
Figure 4 A multi-layer approach to freight mobility in port-hinterland dynamics

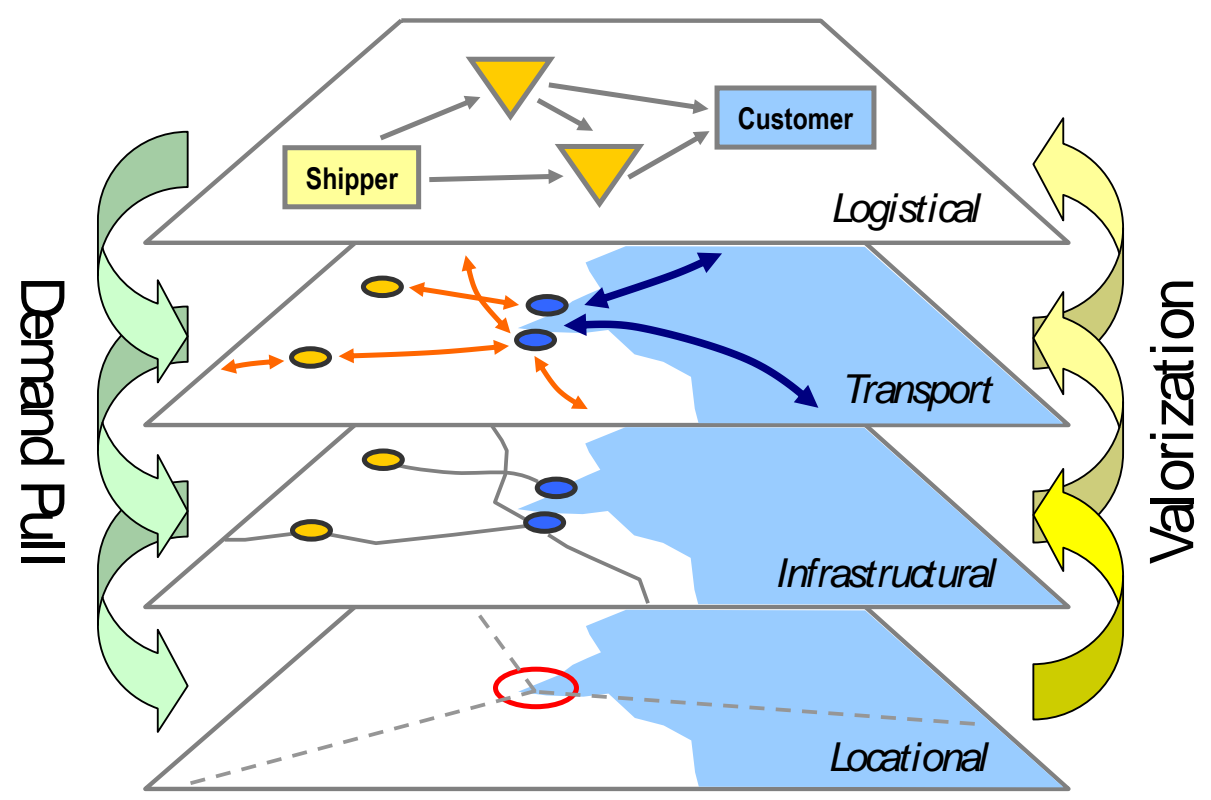

Source: Based on Notteboom \& Rodrigue (2008) and Notteboom (2000).

Nowadays, landlord port authorities are more and more viewed as independent commercial undertakings aiming at full cost recovery and a rapid response to the customer. Port managers aim at making the port attractive to users, by providing a competitive supply of services for carriers and shippers. Inland services are an integral part of that supply. However, the traditional tools in the hands of port authorities typically are confined to the port area itself: investments in docks/berths, concession policy and tariff policy as regards port dues. Given the local nature of revenue sources, many port authorities tend to have a rather local focus and strongly promote activities within the port perimeter that could increase the local revenue base.

Ports and thus also the managing bodies of these ports are facing some serious challenges with respect to hinterland connections. Ensuring mobility of freight (and port workers) is, or at least should be, a key concern to port authorities. Port managers should aim at achieving integrated systems, combining the use of different modes, where appropriate on the same journey (combined or multimodal transport) and with special attention to the use of environmental friendly transport modes. A coherent and internal consistent mobility strategy requires a multi-faceted approach in which organizational/governance, economic and technological evolutions are considered. Based on insights from the scientific literature (see e.g. De Langen, 2008), we can set out five conditions an efficient hinterland strategy should meet:

1. Provide sufficient capacity of hinterland infrastructure and in the interface between port and hinterland infrastructure: this condition links to the infrastructural layer;

2. Guarantee the efficient use of hinterland infrastructure: this condition links to the transport layer, but also supposes actions at the logistical layer in terms of coordination and orchestration;

3. Good coordination of the transport chain;

4. Sustainable from an environmental point of view. The sustainability condition applies to the infrastructural layer, transport layer and logistical layer; 
5. Attractive services (price and quality) of the service providers in the transport chain (terminal operators, carriers, ...), i.e. the transport layer.

Many of these conditions and challenges go beyond the narrow geographical limits of the port, thereby confirming the need for an increasing focus on "port regionalization" as the newest phase in the development of ports (Notteboom and Rodrigue, 2005). Regionalization expands the hinterland reach of the port through a number of strategies linking it more closely to inland freight distribution.

\section{Locational layer}

The locational layer relates to the geographical location of a port vis-à-vis the economic space and forms a basic element for the intrinsic accessibility of a seaport. A good intermediate location can imply a location near the main maritime routes and or near production and consumption centers such as gateway ports. For gateway ports, a good location is a necessary condition for attaining a high intrinsic accessibility to a vast hinterland, which often builds upon the centrality of the port region. It becomes a sufficient condition when the favorable geographical location is valorized by means of the provision of efficient infrastructures and transport services.

The freight mobility challenges at the locational layer are mainly related to shifts in the economic importance of specific (core) hinterland regions which might improve or deteriorate the intrinsic position of a port vis-à-vis the main economic centers in the hinterland. For example, a port with a strong reliance on cargo flows to a specific nearby economic region might see its position weakened if the import and or export flows from this region decrease significantly. In other words, the location of a port must always be assessed in relation to the (economic) importance of its hinterland. Structural changes in the economic geography of this hinterland can make the port's location less or more favorable. Another major challenge for ports is to finds ways to overcome a locational disadvantage compared to rival ports in view of serving a specific hinterland region (see also discussion on infrastructural and transport layers).

There is also a maritime dimension to a port's location, i.e. the geographical position vis-à-vis the global shipping networks and main maritime trade lanes and the related nautical accessibility of the port. While maritime accessibility is beyond the scope of this report, it is important to note that a good location vis-à-vis the hinterland can be seriously undermined in case the nautical accessibility profile of the port is not sufficient to accommodate the typical vessel size used on the relevant trade lanes.

\section{Infrastructural layer}

The infrastructural layer involves the provision and exploitation of basic infrastructure for both links and nodes in the transport system. This is where the intrinsic accessibility is valorized since a port site has little meaning unless capital investment is provided. The availability of adequate infrastructure in transport nodes (seaports and inland terminals) and on the links/corridors in the network is a prerequisite for the development of activities by transport operators (transport layer) and logistics players (logistical layer). Infrastructure should act as a strong enabler of port-related market dynamics that lead to efficient and sustainable co-modal freight transport services. Ports commonly face a range of freight mobility challenges at the infrastructural layer. 


\section{The realization of infrastructure takes (too much) time}

The planning and construction of major port and inland infrastructures typically takes many years. Large transport infrastructure projects take a lot of time to be implemented because of (1) land availability issues in densely populated areas; (2) ever more stringent requirements regarding economic, mobility and ecological evaluation (e.g. social cost-benefit analysis, environmental impact assessment, mobility impact studies, etc..); (3) stakeholder involvement in the planning process; (4) complex decision-making processes due to the involvement of and potential overlap in jurisdiction between the various levels in public policy making. The resulting slow responsiveness of infrastructure to changes at the logistical and the transport level are key to explaining under-capacity (congestion) and/or overcapacity situations in inland freight networks and port systems. Moreover, a poor responsiveness of infrastructure development to the demand at the transport and logistical layers leads to negative effects on market players. Infrastructure investments not valorized by market players have to be avoided.

The time factor plays an important role in any infrastructure project appraisal. First there is the timing of the trajectory from conception of a project to the final decision making. The whole procedure should be finalized within an acceptable timeframe. Guidelines on project appraisal generally do not always contain clear stipulations on the timing for completion of the SCBA (social cost-benefit analysis) and other studies. The timing of the SCBA is determined by the broader decision-making trajectory. Deadlines are often put forward for formal steps in the decision-making process. Second, there is the tension between the long-term focus in infrastructure planning/realization on the hand and the short-term developments in business cycles and market developments on the other. Markets change almost overnight, so companies typically use a short planning horizon of a few years. The shorter business cycles and economic cycles make that it becomes increasingly difficult to develop a long-term focus in the framework of transport projects. Long time series about flows are at the core of any transport infrastructure appraisal, but the uncertainty of long-term developments becomes more apparent. Scenario building and risk analysis have therefore gained in importance when considering transport infrastructure appraisal. Iterative processes are gaining ground as they are generally considered as the way forward in view of providing a reasonable understanding of whether, in the light of changing circumstances, the project proposal is likely to remain good value for money. Iterations in a project evaluation procedure often involve a step-wise approach. The detail and accuracy of the data provided increases as the evaluation progresses from the initial steps of identifying and appraising the project alternatives to the final steps in the procedure.

As the dynamics in the macro-economic and logistical hinterland is high, long delays in the realization of physical infrastructures could ultimately lead to a misallocation of resources. Hence, the market conditions might change considerably in the time-span between the planning phase and the actual realization of an infrastructure. So, an infrastructure investment which at the time of its conception seemed feasible and market-driven, could end up as an investment in the wrong place, at the wrong time, for the wrong market and using the wrong technology.

\section{Pressure on the availability of government funds}

Historically, governments have fully or partially funded the majority of large infrastructure works in ports and the hinterland. Many governments have curbed or at least restricted their financial participation as they face declining available funds. This development has already resulted in a more stringent selectivity of governments when evaluating infrastructure projects and the search for alternative financial solutions through Public-Private Partnerships (PPPs) and other financial instruments. At the same time, environmental departments and spatial planning authorities have gained a lot of power in the process that leads to project approval and the issuing of building permits for 
dredging works, quay walls and hinterland infrastructure. This might imply that the decision making power and possibly even the public funds with respect to infrastructure investments are more dispersed over several ministries or government departments.

Given rising budget constraints, procurement routes are increasingly considered, including the role of the private sector in the financing of the project (public-private partnerships). This trend poses great challenges to the transport project appraisal procedures as potential partnering arrangements and its implications on costs and benefits sharing should be identified early in the process.

Cost overruns are typical for public transport infrastructure. There is a demonstrated, systematic, tendency for project appraisers to be overly optimistic (Flyvbjerg, 2002). Optimism bias has played a major role in e.g. the underestimation of construction costs or the overrating of indirect benefits of a project. Dealing with optimism is slowly being internalized in the evaluation process, for example via an explicit adjustment procedure to redress the systematic optimism. Sensitivity analyses are now broadly used to test assumptions about operating costs and expected benefits. Project proposals are typically reviewed more than once in terms of impact of risks, uncertainties and inherent biases.

\section{Traffic management and the use of IT to optimize infrastructure use}

Traffic management is an important cornerstone of first tier measures directly impacting on the demand supply balance of transportation infrastructure. The network structure of a road system implies that congestion on one road segment can have serious effects on other segments. The same is true for the rail network, and to some extent for inland waterways (although inland waterway networks typically have a treelike structure not allowing lateral connections between line segments). Governments are challenged to pool powers and resources to avoid fragmentation of responsibilities for all aspects of traffic management across the various levels of government. These aspects relate to co-operative and coordinated strategic planning, regulation, facilitation and law enforcement in respect of traffic matters by the national, regional, provincial and local spheres of government.

The use of IT in managing infrastructure planning and use is only going to become more important by 2030. Advances in infrastructure layout, traffic management systems and the introduction of fully autonomous cars and vehicles will further move transport systems towards highly guided systems. Rail and barge transport have already moved strongly in the direction of fully guided systems with the introduction of advanced rail and barge traffic management systems. Also in road transport it is the expectation we will move from a situation where the individual driver still has a lot of control on routing, speed, etc., of the vehicle to a situation where many of these decisions might be fully or partially taken over by traffic systems built in or outside of the vehicle. The advantages of guided transport systems for seaports are mainly found in the area of proactive planning of terminal and inland transport operations. A possible disadvantage is that in highly guided systems the flexibility to make last minute changes is lower (we refer in this respect to the fixed train paths system used in rail which does not leave a lot of room for last minute alterations in the train schedules).

Traffic management with respect to land transport is typically the responsibility of government agencies such a traffic centers or infrastructure managers. However, some port authorities are keen on assuming a (partial) responsibility as well. For example, the Municipality Rotterdam, Rotterdam Metropolitan Region, Ministry of Transport, Public Works and Water management and Port of Rotterdam Authority have established the so-called 'De Verkeersonderneming' in July 2008 to ensure awareness and a strong decrease in traffic congestion during the A15 road constructions. The A15 is a vital road link connecting the outer port area in Rotterdam (Maasvlakte 2 and Maasvlakte 1) to the German hinterland. It is also the main road artery connecting the different areas in the port of 
Rotterdam. Port of Rotterdam Authority took up this responsibility as it is vital the port and the A15corridor remain accessible during the construction work.

Other ports, together with relevant local or regional public entities, have imposed quality standards coupled with access restrictions. A port authority may impose conditions for access to the infrastructure networks (directly into the port area, and through agreements with infrastructure managers outside the port). For example, the Port Authority of Los Angeles imposes strict environmental standards for vehicles that want the port area. Trucks that do not meet the environmental standards are kept outside of the port. The imposition of conditions in the concession agreements with terminal operators may also belong to this category. An example: the latest generation of concession agreements in Rotterdam with respect to container terminals imposes certain conditions on the operator terminal on the modal split linked to a system of penalties or bonuses (coupling with pricing). The concession agreements in the port of Antwerp typically include maritime throughput guarantees, but no modal split guarantees.

\section{The side effects of improving land infrastructure}

The development of large scale intermodal line infrastructures increases the mobility of logistics and economic activities. Trunk lines to major gateways give inland regions a better accessibility to overseas markets. Infrastructure thus acts as a facilitator to increase the participation of land-locked and peripheral regions in global production and logistics networks. Infrastructural developments can also multiply the routing options available between specific inland regions and overseas regions and thus increase and extend port competition. Inland regions typically vie for a good accessibility to more than one gateway port. Infrastructural developments make that (large) gateways face less 'resistance' in reaching the natural hinterland of other ports and promotes inter-port competition.

When logistics activities spread alongside the transport corridors to the more distant (foreign) hinterland ports might face criticism of some community groups arguing that there is an imbalance between the benefits and costs for the local community of having larger and larger ports. This viewpoint is a breeding ground for major socio-economic confrontations related to port and hinterland infrastructure development. As such, port managers and government bodies nowadays (have to) spend a lot of time in trying to make sure that new port and infrastructure developments are socially broadly based. Ports cannot take broad public support for development plans for granted. This aspect of port competitiveness will undoubtedly become more important in the near future as resources such as land are becoming scarcer and as broader social and environmental functions are challenging the economic function of seaports. The more the benefits of ports extend to a vast hinterland area beyond the port region, the more energy will have to be put in embedding the port in the local community, certainly when it comes to seeking infrastructure developments.

\section{The debate on infrastructure charging vs. road pricing}

The pricing of the use of transport infrastructure remains a hot topic. In rail, the gradual European rail liberalization process which started in 1991 led to a separation between infrastructure managers (IM) and railway undertakings (RU). The RU pay a user fee to the IM based on distance covered and cargo load. Inland waterway managers might charge fees for barges using the waterways they manage, although in practice on most waterway sections these fees are very low or even non-existent. In road transport, most of the EU states have introduced toll systems in one way or another. Basically there are two different systems: a vignette, which covers a period of time, or alternatively a toll for a certain stretch of road. Austria for instance makes use of the vignette. Italy and France generally use a pay-asyou-go system for certain toll roads, i.e. drivers only pay for the distance on a specific road. In countries like Germany, Belgium and the Netherlands, only a handful of road transport infrastructures 
are run by commercial or semi-commercial enterprises and involve some sort of toll or charge: e.g. the Liefkenshoek Tunnel in Antwerp, connecting the right bank to the left bank of the port, the Westerschelde Tunnel in Zeeland, connecting the Dutch port cities of Terneuzen and Flushing, and the Warnow Tunnel in the port city of Rostock in northern Germany. It is interesting to observe that these toll tunnels are in or near seaport areas; which is logical given the presence of water masses affecting the routing of flows in port areas.

All over Europe, initiatives are unfolded to develop and implement kilometer charges. We expect that by the reference year 2030, all over Europe such pricing systems will have been implemented and will be fully operational. For example, Germany is preparing the introduction of a light vehicle toll. The new charge would begin in 2016 and foreigners would be able to buy a 10-day pass for around 10 euro. A two-month pass would cost around 20 euro while a yearly pass would go for some 100-150 euro. While vehicles registered in Germany would also have to pay the charge, their owners would be compensated by an equivalent reduction in a separate vehicle tax. German residents would need to display a special toll sticker on their cars. The new toll, if implemented, is expected to raise about 2.5 billion euro in revenue over four years.

The discussion on the pricing of the use of transport infrastructure cannot be treated in isolation from wider fiscal, environmental and social policies. Moreover, it is essential to make a distinction between charges that are aimed at recovering the infrastructure costs and those charges that are aimed at internalizing the so-called external costs (mainly environmental and congestion costs) in the total transport price. For example, the principal objective of congestion pricing is to alleviate congestion by implementing surcharges for the use of selected congested facilities during peak traffic periods. By shifting some trips to off-peak periods, to routes away from congested facilities, or to higheroccupancy vehicles, or by discouraging some trips altogether, congestion pricing schemes would result in savings in time and operating costs for both private and commercial vehicles, improvements in air quality, reductions in energy consumption and improvements in transit productivity. Congestion pricing also promises to generate large amounts of new revenues which could be used to provide improved transportation alternatives or for other purposes. Road infrastructure costs are not the focus of congestion pricing. In many of the proposed or planned schemes the primary aim of the charges is not always clear. For example, the vignette system is poor from an ecological and congestion management viewpoint. Those who do not use their car that often or only use the car in non-peak hours would pay as much as those who use their car frequently also during peak hours. Existing costs should be apportioned rationally, and that external costs must be apportioned among all modes of transport at the same time to avoid distortions of competition.

\section{Transport layer}

The transport layer involves the operation of transport services on links and corridors between the port and other nodes within the multimodal transport system and the transshipment operations in the nodes of the system. It is a matter of volume and capacity.

The rise of co-modality and associated transport corridors have a major structuring effect on the hinterland reach of seaports. Not only has co-modality given incentive for ports to expand their hinterland reach. Hinterlands also became more discontinuous in nature, especially beyond the immediate hinterland of the port. Conventional perspectives based on distance-decay are ill-fitted to address this new reality. Hence, high-volume intermodal corridors typically offer a more favourable relation between transport price, lead time and distance than the conventional/continuous inland transport coverage. The more co-modality serves as a weapon in port competition, the more ports become dependent on the intermodal carriers offering services along the intermodal corridors. 
The rise of corridors is a highly relevant development to any policies aimed at stimulating comodal solutions (road-rail, road-barge, rail-barge and other combinations involving short sea shipping). However, it has to be underlined that co-modal solutions based on barges or rail prove to be competitive on a number of high-density traffic corridors (e.g. the Rhine axis, some Alpine routes, etc..) or in specific niche markets, but cannot serve as a European-wide alternative for road haulage.

\section{Matching supply and demand: bottlenecks and instable capacity supply}

Transport operations are hindered by bottlenecks in a transport system. These bottlenecks can take various forms. First, some bottlenecks occur due to regulatory/political frameworks or decisions, e.g. via stringent vehicle or environmental standards, access and regulation, priority rules for specific groups of infrastructure users or night time bans. Second, bottlenecks might also be the results of operational inefficiencies by transport operators or logistics service providers caused by a lack of information, lack of cooperation due to cutthroat competition, etc. Third, there are the physical bottlenecks caused by a demand for freight transport that exceeds available capacity of infrastructure. The capacity is not only determined by the line infrastructure in place, but also by the infrastructure in nodes (terminals, etc..) and junctions and the IT and traffic management systems.

Even when sufficient transport infrastructure capacity is in place to support port-hinterland freight movements, the steady supply of transport operations can be hampered by:

- The mix of freight flows with passenger flows (see next section);

- Weather circumstances: e.g. low water levels on rivers negatively affecting load factors for barges or making barge transport virtually impossible on some river stretches; snow and ice conditions affecting rail transport operations and road transport, etc... Heavy weather on the open sea such as the North Atlantic can also have an impact on land transport as the resulting schedule unreliability of deep-sea vessels might affect schedules of rail and barge operators and affect berthing availability for barges in seaports;

- Incidents and accidents: e.g. traffic accidents blocking part of the infrastructure for a period of time; strikes resulting in a partial blockage of key road, rail or barge infrastructures in the port or the hinterland;

- Peaks induced by the imperatives of modern supply chain management. In theory, one could try to spread inland freight flows over time so to avoid peaks. However, transport operators and logistics service providers need to take into account the supply chain requirements of the cargo owners and the operational considerations of assets in the chain (e.g. the opening hours and working methods in distribution centers located in the immediate or distant hinterland of the port). As a result, it is very challenging for transport operators to achieve a more or less even spread of freight flows during the day or throughout a week/month. Driving change in demand patterns and practices is difficult to achieve, certainly in the short or medium term.

\section{The mix of passengers and freight}

Many of the inland transport infrastructures of ports are developed for mixed use by passengers and freight. A notable exception is the pipeline, as pipeline networks are fully dedicated to goods transportation. While inland waterways are predominantly used for freight, in certain regions barge operations can be heavily affected by yachts, sailing boats, river cruises or other form of water tourism. In seaports, deep-sea vessels typically have priority over barges. The mix of passengers and freight is most visible in road transport and rail transport. In particular, heavy commuter traffic on major railway axes can make these rail infrastructures virtually unavailable to freight transport during peak hours. Dedicated freight tracks are scarce in Europe, with the Betuwe line in the Netherlands 
being one of the few exceptions. The second railway link to the port of Antwerp is also conceived as a dedicated freight track.

Heavy commuter traffic on the roads not only causes congestion costs for people but also for goods and transport assets. These congestion costs typically manifest itself in the form of direct time costs to the trucking company (e.g. wages, fuel, capital costs, opportunity costs in terms of subsequent transport tasks, etc.). Moreover, congestion can also have a significant cost impact on the cargo and the broader logistics and economic structure (e.g. higher inventory costs related to safety stocks, disruptions in production or distribution networks, etc.).

\section{Cargo bundling}

In an ideal situation operators in rail and barge transport are able to run frequent shuttles between a seaport terminal and an inland destination. From the standpoint of the operators, the shuttle is the most economical form of train or barge operation, as there is no need for time-consuming and expensive wagon regrouping operations in marshalling yards or transshipment between barges. However, the necessary base volume is high. Figure 5 presents two examples of the annual freight volume in TEU that is required (1) to run a shuttle train with a capacity of $75 \mathrm{TEU}$, an average capacity utilisation of $80 \%$ and a frequency of three departures per week; (2) to run a scheduled barge service with a unit capacity of 208 TEU, an average capacity utilisation of $80 \%$ and a frequency of four departures per week.

Figure 5. Relation between service frequency, unit capacity and annual transported volume (80\% utilisation of shuttle)

Frequency per week

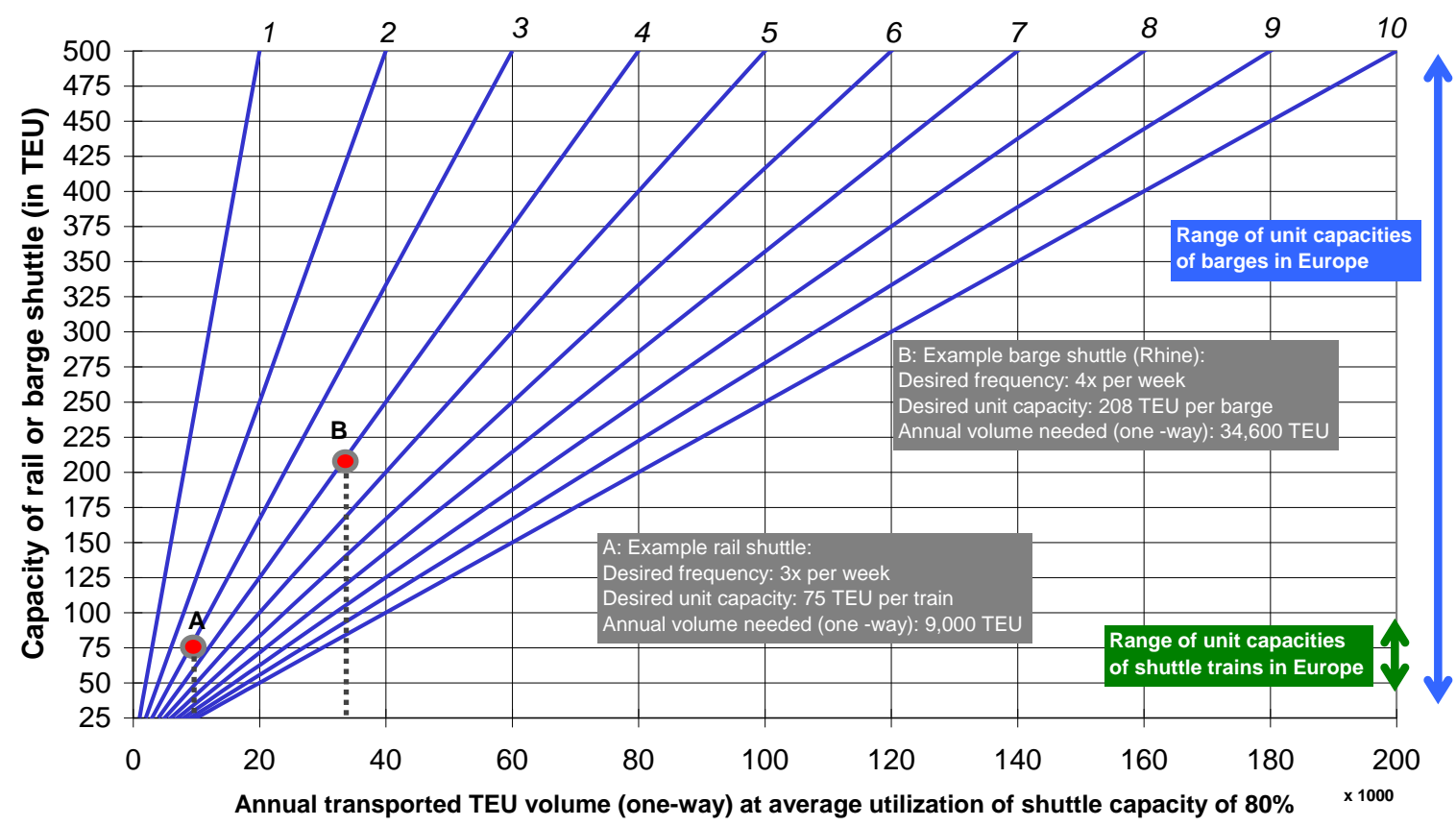

Source: Based on Notteboom (2004) and Notteboom (2009). 
In practice, transport operators typically face challenges in reaching the required base volume to run scheduled services with a large unit capacity at a high frequency. These difficulties can be overcome by bundling cargo either (1) in the seaport or (2) in the hinterland.

Inland hubs are key if an operator opts for cargo bundling in the hinterland. Major European seaports generally generate enough critical mass to install a number of direct shuttle trains to a limited number of key destinations in the immediate hinterland. For the more distant hinterland, however, the volumes not always allow direct shuttle trains on a frequent basis. In view of finding the right trade-off between frequency and volume, numerous cargo bundling networks have emerged. The nodes within these networks are connected by frequent block and shuttle trains with capacities for a single train combination ranging from 30 up to 95 TEU. The problems related to the fluctuating volumes and the numerous final destinations are addressed by bundling container flows in centrally located nodes in the more immediate hinterland (e.g. the role of Duisburg vis-à-vis the ports of Antwerp, Rotterdam and Zeebrugge). One problem with these cargo bundling networks is that they are highly vulnerable to cargo fluctuations. For example, rail liberalisation in Europe has led to the entry of new railway operators who might introduce competing direct shuttle trains on a spoke of an established hub-andspoke network of an incumbent firm (often an intermodal subsidiary of a former national railway company). This has a negative effect on cargo volumes on the spoke and might lead to the collapse of the whole hub-and-spoke system. Consequently, once a rail-based hub-and-spoke network is installed, the associated rail operator is continuously challenged to shift to a (downsized) system of direct shuttle trains. When it comes to inland barge transport, cargo bundling in the hinterland is achieved through multi-porting in a navigation area. For example, barge shuttles link the seaports of Antwerp and Rotterdam with the navigation areas on the Rhine and the Danube on a multi-porting basis: an inland vessel loads containers in a Benelux seaport and then sails to a specific navigation area (e.g. lower Rhine) to load and discharge its cargo at various inland terminals before returning non-stop to the seaport. The scheduled services from the Benelux seaports to navigation areas outside the Rhine basin are not organised on a multi-porting basis, i.e. both Antwerp and Rotterdam have direct river services to almost each non-Rhenish terminal separately. None of the container terminals along the Rhine serves as inland hub for other river ports.

Two extreme systems exist to bundle cargo in the seaport (see also figure 6): at the one extreme the vehicle (i.e. barge or train combination) calls at various deep-sea container terminals in order to fill the available capacity. At the other extreme all containers bound for a specific inland shuttle are brought to one or two central transhipment points through a network of separate intra-port services by truck, barge or rail. In the first option, barges and trains consume time while collecting hinterland cargo. The use of one or two central loading/discharging points in the port area can dramatically reduce port time for barges and train combinations, but incurs extra costs related to the operation of inter-terminal container transfers and extra container handlings. The desired configuration is highly dependent on the spatial lay out of the port area (cf. inter-terminal distances), operational characteristics of terminals, berths and transport equipment and the decision of who will have to bear the costs of inter-terminal transfers (shipping line, terminal operator or any other party). 
Figure 6 Container bundling concepts in multi-terminal container ports

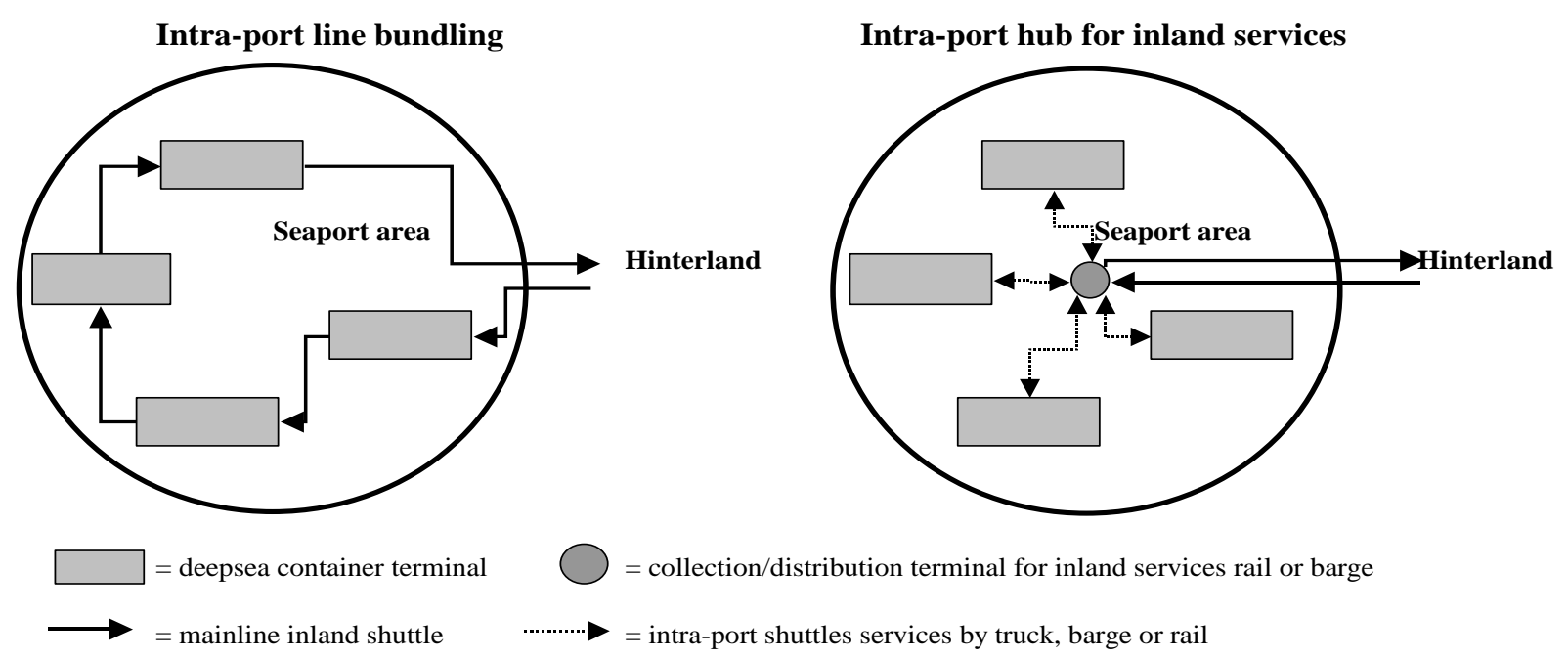

Source: Based on Notteboom \& Konings (2004).

\section{Benefiting the most from a changing European rail sector and thriving on a leadership role in European barge transport}

Market players continue to express concerns over the reliability and the commercial speed of European rail services. European rail logistics are highly complex. The rail liberalization process should lead to real pan-European rail services on a one-stop shop basis. All over Europe, new entrants are emerging. The backbone of rail services out of the load centers in the Hamburg-Le Havre range is formed by direct shuttle trains that offer uninterrupted services between a port and one point of destination at a fixed time schedule and a fixed composition of wagons (typically around 70 to 80 TEU capacity). At present, intermodal transport accounts for some $10 \%$ of trans-Alpine traffic between Italy and France and some $20 \%$ in Germany and Italy. On some tracks, such as the CologneMilan corridor, the figure is as high as $40 \%$. The profitability of a lot of individual direct shuttle trains even to the immediate hinterland of the north European load center ports remains insecure. As a result, a new direct shuttle service is often terminated within a time span of less than one year, simply because cargo availability is low or highly fluctuating. Some carriers and rail operators have resolved the problems related to the fluctuating volumes and the numerous final destinations by bundling container flows in centrally located nodes in the more immediate hinterland (see previous section).

Today, the port of Antwerp offers a blend of hub-based networks, direct shuttles, inter-port shuttles and block trains. Rotterdam and Antwerp each have between 150 and 200 intermodal rail departures per week. Le Havre features only a limited number of direct shuttles, but is well connected to the hub-and-spoke network assembled around a central node near Paris. Hamburg's rail connections outperform all other ports in numbers and in traffic volumes by rail (i.e. close to 2 million TEU). German container terminal operators are directly involved in intermodal rail transport. The German case is quite unique in the Hamburg - Le Havre range. Smaller container ports in the range tend to seek connection to the extensive hinterland networks of the large ports by installing shuttle services either to rail platforms in the big container ports or to master rail hubs in the hinterland.

Barge container transport in Europe has its origins in transport between Antwerp, Rotterdam and the Rhine basin, and in the last two decades it has also developed greatly along the north-south axis between the Benelux and northern France. Antwerp and Rotterdam together handle about $95 \%$ of total 
European container transport by barge. Volumes on the Rhine have increased from 200,000 TEU in 1985 to some 1.8 million TEU in 2012 leading to higher frequencies and bigger vessels (figures Central Commission for Navigation on the Rhine). The fact that barge traffic is primarily concentrated in only two maritime ports (Antwerp and Rotterdam) makes it easier to benefit from economies of scale in barge services. Rotterdam has a strong position on barge traffic from/to the lower Rhine and middle Rhine, whereas Antwerp and Rotterdam are equally strong on the upper Rhine.

The growing realisation of the potential offered by barge container shipping has led to a wave of investment in new terminals over the past 15 years, in northern France, the Netherlands and Belgium. The Benelux and northern France now have more than 35 container terminals, about as many as in the Rhine basin. In 1991 there was still no terminal network on the north-south axis (only two terminals), while the Rhine basin already had 24 container terminals. The bulk of the barge services is controlled by independent barge operators. They have always shown a keen interest in the exploitation of inland terminals. About two thirds of all terminals in the Rhine basin are operated by inland barge operators or the logistics mother company of a barge operator (e.g. Rhenus). The remaining terminals are operated/owned by stevedoring companies of seaports or inland port authorities (e.g. Port Autonome de Strasbourg). Stevedoring companies and forwarders have understood that inland terminals can strengthen their position in the market. In many cases, inland terminals serve as extended gates for deep-sea terminals.

\section{Capitalizing on inland ports and the emergence of logistics poles}

The dynamics in logistics networks have created the right conditions for a large-scale development of inland ports throughout Europe. The range of functions of inland logistics centers is broad from simple cargo consolidation to advanced logistics services. Inland terminals can be incorporated as 'extended gates' to seaport terminals and as such can help to reduce container dwell times on seaport terminals ${ }^{2}$. Many inland locations with multimodal access have become broader logistics zones. They not only have assumed a significant number of traditional cargo handling functions and services, but also have attracted many related services, a.o. distribution centres, shipping agents, trucking companies, forwarders, container repair facilities and packing firms. Logistics zones are usually created within the framework of regional development policies as joint initiatives by firms, intermodal operators, regional and local authorities, the central government and/or the Chambers of Commerce and Industry.

Quite a few of these logistics zones are competing with seaports for what the location of European distribution facilities are concerned. The availability of fast, efficient and reliable intermodal connections is one of the most important prerequisites for the further development of inland terminals. The interaction between seaports and inland locations leads to the development of a large logistics pole consisting of several logistics zones. Seaports are the central nodes driving the dynamics in such a large logistics pole. But at the same time seaports rely heavily on inland ports to preserve their attractiveness.

The 'port regionalization' phase expands the hinterland reach of the port through a number of strategies linking it more closely to inland freight distribution centers (Notteboom and Rodrigue, 2005). The phase of regionalization brings the perspective of port development to a higher geographical scale, i.e. beyond the port perimeter. The port regionalization phase is characterized by a strong functional interdependency and even joint development of a specific seaport and (selected) logistics platforms in its hinterland. The transition towards the port regionalization phase is a gradual and market-driven process that mirrors the increased focus of market players on logistics integration. 
Many ports are reaching a stage of regionalization with varying degrees of formal linkages between the nodes of the observed networks:

- Port authorities can consider co-operation with inland ports in the field of traffic management, land issuing, hinterland connections and services, environmental protection and research and development $(\mathrm{R} \& \mathrm{D})$.

- Port authorities could invest in barge and rail terminals. An example: HHLA Hamburg has also invested in rail terminals in the hinterland. However, the willingness to invest is reduced by strategic considerations. A port authority might be less inclined to invest if competitors also get benefits from it (cargo spill-over effects and the free-rider problem).

- Port authorities may invest in a port community system (PCS) with an application that exceeds the port boundaries. For example, the Port of Barcelona has invested in a port community system that is used not only in the port itself but also in some hinterland nodes (called tm or terminal maritime such as in Toulouse, Zaragoza, Madrid and Lyon).

- Port authorities may consider co-investing in hinterland corridors. For example, the ports of Los Angeles and Long Beach perform co-management and have also invested in the construction of the Alameda rail corridor linking the ports with the intermodal rail terminals around Los Angeles.

- Finally, port authorities can participate in the offer of hinterland services. For example, HHLA in Hamburg is actively involvement in the provision of rail shuttles.

There are a number of reasons to opt for a port regionalization strategy. Port authorities understand that with the creation of logistics poles, port benefits might leak to users in inland locations. A port strategy solely based on the local port area is not suited to address this threat in an adequate manner. An active port regionalization strategy makes it possible to benefit the most from the reshaped networking among nodes. Moreover, port users' focus on logistics networks makes a wider approach to port management imperative. The port community has to fully benefit from synergies with other transport nodes and other players within the networks of which they are part.

Notwithstanding these advantages, port authorities have always been rather reluctant to engaging in advanced forms of strategic partnerships with inland ports. Port managers fear to losing added value and employment by 'giving away' activities, to losing captive cargo (port related companies in the hinterland are less dependent on one port for their maritime import and export) and to losing clients as these might consider the cooperation with one specific hinterland location as a market restriction or distortion. In practice, a well-balanced port regionalization strategy does not imply a loss of port activity. It should enable a port authority to develop new resources and capabilities in close cooperation with other transport nodes and with mutual interests served. Sometimes very simple coordination actions can substantially improve inland freight distribution, with benefits for all parties involved.

Large seaports generally have a broad financial base to engage in a well-balanced port networking strategy, although substantial differences exist even among the largest ports. Smaller ports and new ports have to rely solely on very simple co-ordination actions to substantially improve inland freight distribution, with benefits for all parties involved.

\section{Inland transport price challenges}

The pricing levels of inland freight mobility are affected by several developments. One the one hand, efficiency gains, economies of scale and network economies in transport operations should lead to a lower transport price per cargo unit, ton or ton-km. However, these gains are counterbalanced primarily by the effects of (a) higher fuel costs, (b) more stringent environmental requirements and 
standards, and (c) the tendency towards an increased application of environmental and congestion pricing in view of internalizing external costs. The level of trade or route imbalances affects the utilization degree of the transport equipment and thus affects price level differences between the outward leg and the return leg of a transport service.

Next to the expected increases in land transport costs in absolute terms, we expect a continuation of the gradual shift in chain costs from sea to land. Container transport provides a good example. Scale increases in vessel size and alliance co-operation have lowered ship system costs, but at the same time intermodal costs share an increasing part of the total cost. The portion of inland costs in the total costs of container shipping typically ranges between $40 \%$ and $80 \%$. The shift from vessel costs to landside costs is enhanced by transport price evolutions. For example, the freight rate and additional charges (including BAF, CAF and THC, but excluding administrative costs and time costs) on a port-to-port basis with a post-panamax vessel between Shanghai and the port of Antwerp amount to some EUR 0.12 per FEU-km (EUR 2300 for $11000 \mathrm{~nm}$ ), while inland haulage per truck from north European ports usually ranges from EUR 1.5 to 4 per FEU-km, depending on distance and weight. By barge, the price ranges between EUR 0.5 and 1.5 per FEU-km (excluding handling costs and pre- and end haul by truck). The price difference per FEU-km between inland transport and long-haul liner shipping ranges from a factor 5 to a factor 30, further supporting the notion that inland logistics is one of the most vital areas for the competitiveness of seaports.

\section{Logistical layer}

The logistical layer involves the organization of transport chains and their integration in logistical chains. This layer is mostly managerial with a decision making process in terms of the allocation of modes and the booking of transshipment facilities.

Ports have all implemented ways of moving cargo as efficiently as possible through the port and on to intermodal corridors. None of the ports has been able to achieve these outcomes alone. They are all dependent on the development of an innovative range of relationships and network formations with transport operators, logistics service providers and other transport nodes. Coordination and cooperation is needed to form an integrated intermodal service that complies with the requirements imposed by the supply chains that pass through the port.

The call for cooperation and coordination is materializing against the backdrop of large scale consolidation and vertical integration in the logistics industry. The observed vertical integration strategies of the market players have blurred the traditional division of tasks within the logistics chain but at the same time improved the coordination between segments of the chain. Market consolidation has resulted in large port clients who possess a strong bargaining power vis-à-vis terminal operations and inland transport operations. Through a vertical and horizontal integration of their activities market players such as shipping lines, forwarders, transport operators and logistics groups seek to reduce costs, to improve efficiency, to generate revenue and to deliver value and a 'one-stop shop' service to the customer. The provision of integrated services does not always need to coincide with the ownership of the related assets. In many cases, the integration is achieved through close partnerships with other players. 


\section{Notes}

1. ERTMS aims at replacing the different national train control and command systems in Europe through the replacement of existing national automatic train protection systems (ATP) and the development of a radio system for providing voice and data communication between the track and the train.

2. For example, terminal operator ECT in Rotterdam (part of HPH) follows an active strategy of acquiring key inland terminals acting as extended gates to its deep-sea terminals. Through 'European Gateway Services', ECT offers shipping lines, forwarders, transport companies and shippers a variety of services to facilitate the optimal flow of containers between the deep-sea terminals in Rotterdam and the direct European hinterland. The inland network includes the TCT Venlo rail and barge terminals (the Netherlands), DeCeTe terminal in Duisburg (Germany), TCT Belgium in Willebroek (Belgium), ACT in Amsterdam, MCT in Moerdijk, AVCT in Avelgem (Belgium) and LCT in Liège (Belgium). ECT is not the only deep-sea terminal operator developing an active extended gate policy. APM Terminals, DP World and Eurogate are also developing the terminal operator haulage concept aimed at a more active involvement of the terminal operator in hinterland connections by establishing closer relationships with shipping lines and inland operators. 


\section{Bibliography}

Acciaro, M. and A.C. McKinnon (2013), Efficient hinterland transport infrastructure and services for large container ports, Position paper for the OECD/ITF Roundtable, Port Investment and Container Shipping Markets, Santiago de Chile, Chile, 7-8 November.

Bask, A. et al. (2014), "Development of seaport-dry port dyads: two cases from Northern Europe", Journal of Transport Geography, Vol. 39, pp. 85-95.

Bergqvist, R. (2012), "Hinterland logistics and global supply chains", in: D. Song and P. Panayides (eds.), Maritime Logistics: A Complete Guide to Effective Shipping and Port Management, Kogan Page Publishers, 211-232.

Bergqvist, R. and N. Egels-Zandén (2012), "Green port dues - The case of hinterland transport", Research in Transportation Business \& Management, Vol. 5, pp. 85-91.

Bergqvist, R., G. Wilmsmeier and K. Cullinane (eds.) (2013a), Dry Ports - A Global Perspective, Challenges and Developments in Serving Hinterlands, Ashgate Publishing Ltd., Farnham.

Bergqvist, R., G. Wilmsmeier and K. Cullinane (2013b), "Introduction - A Global Perspective on Dry ports", in: R. Bergqvist, G. Wilmsmeier and K. Cullinane (eds.), Dry Ports - A Global Perspective, Challenges and Developments in Serving Hinterlands, Ashgate Publishing Ltd., Farnham, 1-10.

Bergqvist, R. et al. (2014), "Making hinterland transport more sustainable: a multi-actor, multi-criteria analysis", Research in Transportation Business \& Management (forthcoming)

Brooks, M. and J. Frost (2004), "Short sea shipping: a Canadian perspective", Maritime Policy \& Management, Vol. 31:4, pp. 393-407.

De Langen, P.W. (2008), Ensuring hinterland access: the role of port authorities, OECD/ITF Research Roundtable, 'Seaport Competition and Hinterland Connections', Discussion Paper 2008-11, ITF, Paris.

Douet, M. and J.F. Cappuccilli (2011), "A Review of Short Sea Shipping Policy in the European Union”, Journal of Transport Geography, Vol. 19, pp. 968-976.

Flyvbjerg, B. (2002), Underestimating Costs in Public Works Projects, Journal of the American Planning Association, 68 (3), 279-295.

Franc, P. and M. Van der Horst (2010), "Understanding hinterland service integration by shipping lines and terminal operators: a theoretical and empirical analysis", Journal of Transport Geography, Vol. 18, pp. 557-566.

Frémont, A. and P. Franc (2010), "Hinterland transportation in Europe: Combined transport versus road transport", Journal of Transport Geography, Vol. 18, pp. 548-556. 
Giuliano, G. et al. (2008), "Evaluation of the Terminal Gate Appointment System at the Los Angeles/Long Beach Ports", METRANS Project 04-06.

Giuliano, G. and T. O'Brien (2008), "Extended Gate Operations at the Ports of Los Angeles and Long Beach: A Preliminary Assessment”, Maritime Policy and Management, Vol. 35, No. 2, pp. 215-235.

Giuliano, G. and T. O’Brien (2007), "Reducing Port-Related Truck Emissions: The Terminal Gate Appointment System at the Ports of Los Angeles and Long Beach", Transportation Research Part D, Vol. 12, No. 7, pp. 460-473.

Global Insight (2006), Four Corridor Case Studies of Short-Sea Shipping Services, Short-Sea Shipping Business Case Analysis, Submitted to US DoT, August 15.

Gouvernal, E., B. Slack and P. Franc (2010), "Short sea and deep sea shipping markets in France", Journal of Transport Geography, Vol. 18, pp. 97-103.

Grosso, M. et al. (2010), "Short Sea Shipping, intermodality and parameters influencing pricing policies: the Mediterranean case", Netnomics, Vol. 11, pp. 47-67.

Medda, F. and L. Trujillo (2010), "Short-sea shipping: an analysis of its determinants", Maritime Policy \& Management, Vol. 37:3, pp. 285-303.

Monios, J. (2011), "The role of inland terminal development in the hinterland access strategies of Spanish ports", Research in Transportation Economics, pp. 59-66.

Monios, J. and G. Wilmsmeier (2013), "The role of intermodal transport in port regionalization", Transport Policy, Vol. 30, pp. 161-172.

Monios, J. and B. Lambert (2013), "Intermodal Freight Corridor Development in the United States", in: R. Bergqvist, G. Wilmsmeier and K. Cullinane (eds.), Dry Ports - A Global Perspective, Challenges and Developments in Serving Hinterlands, Ashgate Publishing Ltd., Farnham, 197218.

National Ports and Waterways Institute (2004), The public benefits of the short-sea intermodal system; A study prepared for the Short Sea Shipping Co-operative Program (SCOOP), University of Orleans, November.

$\mathrm{Ng}$, A. (2009), "Competitiveness of short sea shipping and the role of the port: the case of North Europe", Maritime Policy \& Management, Vol. 36:4, pp. 337-352.

Notteboom, T. (2000), De invloed van ruimtelijke en logistieke ontwikkelingen in het voorlandachterlandcontinuüm op de positie en functie van zeehavens (The impact of spatial and logistical developments on the position and function of seaports), Ph. D. thesis, RUCA, Antwerp.

Notteboom, T. (2009), Economic analysis of the European seaport system, ITMMA - University of Antwerp: Antwerp.

Notteboom, T. (2010), Dock labour and port-related employment in the European seaport system: key factors to port competitiveness and reform, ITMMA - University of Antwerp: Antwerp. 
Notteboom, T. and W. Winkelmans (2001), Structural changes in logistics: how will port authorities face the challenge? Maritime Policy and Management, 28(1), 71-89.

Notteboom, T. and R. Konings (2004), Network dynamics in container transport by barge, Belgeo, 5(4), pp. 461-477.

Notteboom, T. and J.-P. Rodrigue (2005), Port regionalization: towards a new phase in port development, Maritime Policy and Management, 32(3), 297-313.

Notteboom, T. and J.-P. Rodrigue (2008), Containerization, box logistics and global supply chains: the integration of ports and liner shipping networks, Maritime Economics and Logistics, 10 (1-2), 152-174.

Paixao, A. and P. Marlow (2002), "Strengths and weaknesses of short sea shipping", Marine Policy, Vol. 26, pp. 167-178.

Paixao, A. and P. Marlow (2007), "The Impact of the Trans-European Transport Networks on the Development of Short Sea Shipping”, Maritime Economics \& Logistics, Vol. 9, pp. 302-323.

Perakis, A. and A. Denisis (2008), "A survey of short sea shipping and its prospects in the USA", Maritime Policy \& Management, Vol. 35:6, pp. 591-614.

Roso, V. J. Woxenius and K. Lumsden (2009), "The dry port concept: connecting container seaports with the hinterland", Journal of Transport Geography, 17 (5), 338-345.

Saurí, S. (2006), “Cost structure in a short sea shipping line”, Journal of Maritime Research, Vol. 3 (2), pp. 53-66.

Strandenes, S. and P. Marlow (2000), "Port pricing and competitiveness in short sea shipping", International Journal of Transport Economics, Vol. 27:3, 315-334.

Van den Berg, R. and P. De Langen (2011), "Hinterland strategies of port authorities: A case study of the port of Barcelona", Research in Transportation Economics, Vol. 33, pp. 6-14.

Van den Berg, R., P. De Langen and C. Costa (2012), "The role of port authorities in new intermodal service development: the case of the Barcelona Port Authority", Research in Transportation Business \& Management, Vol. 5, pp. 78-84.

Van der Lugt, L., S. Rodrigues and R. Van den Berg (2014), "Co-evolution of the strategic reorientation of port actors: insights from the Port of Rotterdam and the Port of Barcelona", Journal of Transport Geography, Vol. 41, pp. 197-209.

Wilmsmeier, G., J. Monios and B. Lambert (2011), "The directional development of intermodal freight corridors in relation to inland terminals", Journal of Transport Geography, Vol. 19, pp. 1379-1386. 
